\title{
KADERISASI KEPEMIMPINAN DALAM ORGANISASI DAKWAH RASULULLAH
}

\author{
Dedy Pradesa \\ STID Al-Hadid, Surabaya \\ depra19312@gmail.com
}

\begin{abstract}
Abstrak: Studi ini berangkat dari nilai penting kaderisasi kepemimpinan dan fenomena persoalan sistem kaderisasi kepemimpinan yang ala kadarnya pada organisasi dakwah. Dalam sejarah, Rasulullah telah terbukti mampu mengader pemimpin berkualitas pada organisasinya, maka penting bagi umat Islam, khususnya para pemimpin organisasi dakwah, untuk mempelajarinya. Studi ini bertujuan mendeskripsikan proses kaderisasi kepemimpinan organisasi dakwah Rasulullah. Dasar teoritis yang digunakan adalah konsep kaderisasi kepemimpinan/pengembangan talenta eksekutif Smiliansky dan Yukl, yang dikontekskan dalam organisasi dakwah, sedangkan metodolognyai kualitatif pustaka sejarah. Hasil studi menunjukkan bahwa proses kaderisasi kepemimpinan organisasi dakwah Rasul dilaksanakan dua tahapan, yaitu (1) identifikasi SDM talenta kepemimpinan dakwah, dan (2) pendidikan/pelatihan dan pengembangan kapabilitas SDM calon pemimpin. Dalam identifikasi talenta kepemimpinan dakwah, Nabi memprioritaskan SDM generasi pertama, yaitu kaum Muhajirin, mengingat bukti keimanan, loyalitas dan konsistensi kinerja dalam dakwah serta potensi kepemimpinan. Namun Nabi juga tetap mengidentifikasi talenta kepemimpinan dakwah dalam lapisan generasi SDM sahabat berikutnya, seperti di kaum Ansar, Muslimin pasca penaklukan Mekkah dan putra-putri Sahabat. Dalam proses pendidikan kepemimpinan dakwah, tahap awal menekankan pembentukan keimanan, visi keislaman, mentalitas dan moralitas kepemimpinan dakwah. Tahap selanjutnya berorientasi kemampuan penalaran/pemecahan masalah dan membangun komunikasi pribadi. Pendidikan kepemimpinan dakwah melalui forum pembelajaran, pelibatan dalam forum strategis, pembimbingan personal, serta penugasan sebagai pemimpin kelompok dakwah.
\end{abstract}

Kata Kunci: kaderisasi kepemimpinan, organisasi dakwah Nabi, kepemimpinan dakwah

Abstract: This study originates from the important value of forming cadres of leaders and problematic phenomena on the system of forming cadres of leaders which is conducted perfunctorily in da'wah organizations. Throughout history, the Prophet (PBUH) has proven to be able to form well-qualified leaders in his organization. Therefore, it is important for Moslems, especially the leaders of da'wah organizations, to learn about it. This study aimsto describe process of forming cadres of leaders in the Prophet's da'wah organization. Theoritical basis which is used is Smiliansky and Yukl's concept of forming cadres of leaders / executive talent development, which is contextualized into a da'wah organization. Its method used is qualitative historical literature. The result of study indicates that the process of forming cadres of leaders in the Prophet's da'wah organization was done in two stages, namely (1) identifying the human resources who had talent on da'wah leadership, and (2) educating / training and developing the capabilities of the candidates of leaders. In identifying the talent, the Prophet prioritized the first 
generation of human resource, namely the Muhajirun, considering their proofs of faithfulness, loyalty, and work consistency during da'wah and leadership potency. However, the Prophet (PBUH) also identified any leadership talents from the next generation of companions, like the Ansar, Moslems after the conquer of Mecca and the children of his companions. In the process of educationg da'wah leadership, the early stage emphasized on the forming of faithfulness, Islamic vision, mentality and morality of da'wah leadership. The next stage was oriented to reasoning skills / problem solving and building personal communication. The education of da'wah leadership was conducted through learning forums, the involvement in strategic forums, personal guidance, and tasks as leaders of da'wah groups.

Key words: forming cadres of leaders, prophet's da'wah organization, da'wah leadership

\section{Pendahuluan}

Pemimpin memiliki peranan yang fundamental bagi organisasi. Peran penting pemimpin dapat dilihat dari hakikat kepemimpinan, sebagaimana disampaikan Rivai dan Mulyadi, bahwa kepemimpinan merupakan proses memengaruhi atau memberi contoh, memberi inspirasi dari pemimpin kepada pengikutnya dalam upaya mencapai tujuan organisasi. ${ }^{1}$ Namun yang tidak kalah penting adalah regenerasi atau kaderisasi kepemimpinan dalam sebuah organisasi. Seorang pemimpin organisasi sebagaimana manusia pada umumnya suatu saat akan mengakhiri masa kepemimpinannya, baik dikehendaki maupun tidak. Proses tersebut dapat terjadi secara alamiah, adanya ketentuan periode kepemimpinan seseorang, dan adanya penolakan dari anggota yang menghendaki pemimpinnya diganti. ${ }^{2}$ Oleh karenanya penting bagi organisasi melakukan kaderisasi kepemimpinan, yaitu proses mempersiapkan seseorang untuk menjadi pemimpian pengganti di masa depan, yang akan memikul tanggung jawab penting di organisasasi. ${ }^{3}$ Kaderisasi

1 Vithzal Rivai \& Deddy Mulyadi, Kepemimpinan dan Perilaku Organisasi, (Jakarta: Rajawali Pers, 2012), 3.

2 Ibid., 96.

3 lbid., 96. kepemimpinan merupakan tali pengikat antara masa kini dan masa yang akan datang. Pemimpin tua yang tidak melakukan kaderisasi selama hidupnya, akan menyebabkan keterputusan generasi, yang mewariskan ketidakmengertian kepada generasi muda. ${ }^{4}$ Studi dari Smiliansky menjelaskan bahwa kebanyakan perusahaan besar memiliki suatu proses atau sistem untuk mengidentifikasi generasi talenta masa depan yang diharapkan dalam jangka waktu menengah akan menjadi eksekutif (pimpinan) senior di perusahaan serta sistem untuk mengembangkan talenta tersebut, utamanya melalui pendekatan program pelatihan manajemen. 5 Regenerasi kepemimpinan tidak hanya telah menjadi suatu kesadaran bersama namun tersistem dengan mapan dalam perusahaanperusahaan besar.

Kepemimpinan dan kaderisasi kepemimpinan dalam organisasi dakwah juga tidak kalah pentingnya. Sebab

\footnotetext{
${ }^{4}$ Saiful Falah, "Pendidikan Kepemimpinan M. Natsir dan Implementasinya di Lembaga Pendidikan," Edukasi Islami Jurnal Pendidikan Islam, Vol.04, Juli (2015), 1091.

${ }^{5}$ Jonathan Smilansky, Developing Executive Talent, diterjemahkan Octa Melia Jalal, (Jakarta: PPM, 2008), 169.
} 
organisasi dakwah mengemban sebuah misi dakwah. Dakwah sendiri secara esensi merupakan aktivitas dan upaya untuk mengubah manusia, baik individu maupun masyarakat dari situasi yang tidak baik menjadi lebih baik. ${ }^{6}$ Pada kenyataannya tidak semua lembaga dakwah/sosial telah memiliki kesadaran pentingnya sistem kaderisasi kepemimpinan apalagi sebuah sistem yang mapan. Sebagaimana dijelaskan Yuliati, bahwa kebanyakan sistem regenerasi kepemimpinan pada organisasi pendidikan dan dakwah yang tradisional seperti pesantren dilakukan melalui tradisi bahwa putra kiai atau keluarga terdekatlah yang harus menjadi calon pengganti kepemimpinan pesantren. Sistem kaderisasi dilakukan dengan metode imitasi, diharapkan calon pemimpin dapat menyerap kapasitas keilmuan dan meniru perilaku dari kiai sebagai pemimpin sebelumnya. Namun banyak calon pemimpin yang kurang bisa memenuhi harapan tersebut, sehingga semakin lama kualitas pesantren semakin menurun. ${ }^{7}$ Fenomena tersebut dijelaskan oleh Masyhud, berkaitan dengan dua faktor, yaitu: (a) kepemimpinan yang tersentralisasi pada individu yang bersandar pada karisma serta hubungan yang bersifat paternalistik; (b) kepemilikan pesantren atau organisasi dakwah bersifat individual (atau keluarga), bukan komunal, sehingga otoritas individu kiai sebagai pendiri sekaligus pengasuh sangat besar dan tidak bisa diganggu gugat. ${ }^{8}$

\footnotetext{
${ }^{6}$ M. Munir \& Wahyu Ilaihi, Manajemen Dakwah, (Jakarta: Kencana, 2006), 21.

${ }^{7}$ Kadar Yuliati, "Kaderisasi Kepemimpinan di Pondok Modern Darussalam Gontor Ponorogo Jawa Timur," (Tesis, Pascasarjana UIN Sunan Kalijaga, 2015), 5-6.

8 M. Suthon Masyhud, dkk., Manajemen Pondok Pesantren, (Jakarta: Diva Pustaka, 2008), 15.
}

Persoalan utamanya bukanlah regenerasi kepemimpinan yang bersifat nasab atau keturunan, tetapi bagaimana sistem untuk menyiapkan calon pemimpin di masa yang akan datang, sehingga proses regenerasi kepemimpinan tidak berjalan secara alamiah yaitu regenerasi atau kaderisasi kepemimpinan yang berjalan tanpa ada suatu sistem tertentu atau dengan sistem yang sederhana dan ala kadarnya. Kaderisasi kepemimpinan alamiah memiliki karakteristik: (a) tidak adanya standarisasi kualifikasi kepemimpinan yang diharapkan; (b) tidak adanya metode yang jelas untuk mendapatkan talenta kepemimpinan, dan (c) tidak adanya metode yang efektif dan efisien untuk menyiapkan dan melatih talenta kepemimpinan sehingga dalam jangka waktu tertentu telah siap untuk menjadi pemimpin organisasi di masa yang akan datang.

Fenomena di atas mengindikasikan adanya permasalahan terkait sistem kaderisasi kepemimpinan di lembaga/organisasi dakwah dan sosial. Salah satu ukuran kualitas sistem kepemimpinan dalam sebuah organisasi dapat diindikasikan dari kualitas sistem kaderisasi kepemimpinannya. Hal tersebut juga mengindikasikan perhatian terhadap sistem kaderisasi kepemimpinan di lingkungan organisasi dakwah dan sosial belum sepenuhnya tepat sasaran sehingga berdampak pada perkembangan organisasi yang bersangkutan dan perkembangan dakwah Islam di Indonesia. Ada banyak faktor yang menyebabkan, di antaranya adalah kurangnya kesadaran akan pentingnya sistem kaderisasi kepemimpinan yang efektif, minimnya pemahaman dan kompetensi aktivis organisasi dakwah dan sosial terkait 
keilmuan kaderisasi kepemimpinan, kuatnya kultur atau tradisi kaderisasi kepemimpinan yang bersifat keturunan, dan sebagainya.

Membangun kesadaran dan pengetahuan terkait sistem kaderisasi kepemimpinan di organisasi dakwah, salah satunya dapat dilakukan dengan mempelajari sejarah Nabi Muhammad saw. dalam melakukan kaderisasi kepemimpinan di lingkungan organisasinya. Alasan pemilihan kaderisasi kepemimpinan oleh Nabi Muhammad saw. tidak lain adalah karena beliau berhasil mengader anggota sekaligus sahabatnya menjadi pemimpin-pemimpin besar di masa selanjutnya. Contoh nyata untuk ini adalah kepemimpinan para khulafaur rasyiddin, para khalifah pengganti Nabi, yaitu Abu Bakar, Umar bin Khattab, Usman bin Affan dan Ali bin Abi Thalib. Mereka berhasil mempertahankan eksistensi organisasi Islam sepeninggal Nabi Muhammad. Tidak hanya dari segi kompetensi memimpin dan pemecahan masalah umat, namun mereka (khulafaur rasyiddin) dikenal memiliki integritas dan moralitas yang tinggi. Mereka adalah orang-orang bertalenta yang secara langsung dibina oleh Nabi Muhammad saw.

Muhammad Fathi menjelaskan bahwa Rasulullah telah mempersiapkan pemimpin lain sebagai pengganti beliau untuk ikut serta mengemban amanat dakwah kepada Allah. Rasulullah telah menyiapkan pendamping/pembantu beliau dalam dakwah, generasi kedua dan generasi berikutnya yang dipersiapkan sedini mungkin agar dapat tumbuh dan berkembang sesuai dengan pemikiran sang pemimpin. Rasulullah memilih beberapa orang dalam urusan ini yang dianggap sesuai dengan misi dakwah beliau, kemudian mempersiapkan mereka dengan melakukan pendidikan dan pembekalan (kaderisasi). ${ }^{9}$ Keberhasilan Nabi dalam membina orang-orang luar biasa yang ada di sekitarnya merupakan salah satu faktor yang menyebabkan kebesaran beliau dari segi pengaruhnya terhadap sejarah peradaban manusia, 10 dan sebagai pemimpin. Di sinilah pentingnya bagi umat Islam hari ini, khususnya para aktivis organisasi dakwah untuk mempelajari bagaimana Nabi Muhammad melakukan kaderisasi kepemimpinan kepada SDMSDMnya.

Studi ini bertujuan untuk mengeksplorasi bagaimana proses kaderisasi kepemimpinan dalam organisasi dakwah Rasulullah. Proses kaderisasi terkait tahapan, metode dan perangkat penunjang yang dilakukan oleh Nabi untuk membina/mengader sahabat-sahabatnya sebagai pemimpin organisasi di masa yang akan datang. Fokus masalah yang dikaji, adalah: (1) siapa sajakah subjek-subjek yang terlibat dalam proses kaderisasi kepemimpinan pada organisasi dakwah Nabi? (2) aktivitas-aktivitas apa dan bagaimana sajakah yang menggambarkan paroses kaderisasi kepemimpinan dalam organisasi dakwah Nabi? (3) bagaimanakah hasil dari aktivitas-aktivitas kaderisasi kepemimpinan tersebut? Sehingga, analisis dalam studi ini mencakup subjek-subjek yang terlibat yaitu yang mengader dan yang dikader; aktivitas kaderisasi kepemimpinan yang dilakukan mencakup tahapan/jenis, gambaran pelaksanaan, waktu dan

\footnotetext{
${ }^{9}$ Muhammad Fathi, The Art of Leadership in Islam, diterjemahkan Masturi Irham \& Malik Supar, (Jakarta: Khalifa, 2007), 201-203.

10 Iskandar Al-Warisyi, Substansi Rasulullah dan Sunnahnya, (Surabaya: Yayasan Al-Kahfi, 2001), 97.
} 
tempatnya, serta yang dihasilkan dari proses kaderisasi kepemimpinan tersebut.

Penelusuran terhadap studi terdahulu yang juga mengkaji masalah kaderisasi kepemimpinan dalam organisasi Islam/sosial, di antaranya adalah: (1) "Model Regenerasi dan Kaderisasi Kepemimpinan dalam Islam" dalam Eduka Jurnal Pendidikan, Hukum dan Bisnis. ${ }^{11}$ Studi tersebut mengkaji model regenerasi dan kaderisasi kepemimpinan dalam Islam dari masa Rasul, Khulafaur Rasyidin hingga era Dinasti, yang menunjukkan adanya perbedaan nilai dasar utama dalam kaderisasi kepemimpinan; (2) "Kaderisasi Kepemimpinan Agama Melalui Pondok Pesantren Al-Munawir Krapyak Yogyakarta" dalam Jurnal Penelitian dan Evaluasi. ${ }^{12}$ Studi tersebut bertujuan untuk memahami sifat/karakteristik kepemimpinan Rasulullah dalam proses interaksi yang memunculkan kader pemimpin agama melalui uswah dari kiai; (3) Tesis berjudul Kaderisasi Kepemimpinan Persis (Studi Deskripsi Persis di Kecamatan Bojongpicung Kabupaten Cianjur) karya Nita Erawati Utama. ${ }^{13}$ Studi tersebut mengkaji proses kaderisasi kepemimpinan di organisasi Persis, mulai dari proses perekrutan, pembinaan kader, dan pembentukan kepemimpinan.

\footnotetext{
${ }^{11}$ Saiful Falah, dkk. "Model Regenerasi dan Kaderisasi Kepemimpinan dalam Islam," Eduka Jurnal Pendidikan, Hukum dan Bisnis, volume II, nomor 2, (2016): 67-91.

12 Abdul Qodir dan Sarbiran, "Kaderisasi Kepemimpinan Agama Melalui Pondok Pesantren AlMunawir Krapyak Yogyakarta," Jurnal Penelitian dan Evaluasi, nomor 3, tahun II, (2000): 141-156.

13 Nita Erawati Utama, Kaderisasi Kepemimpinan Persis (Studi Deskripsi Persis di Kecamatan Bojongpicung Kabupaten Cianjur), (Thesis, UIN Sunan Gunung Djati, Bandung, 2010).
}

Aktivitas kaderisasi kepemimpinan pada dasarnya menjadi bagian dari studi perilaku kepemimpinan. Sementara studi perilaku kepemimpinan terhadap kepemimpinan Nabi atau disebut kepemimpinan Kenabian (prophetics leadership) telah banyak dilakukan, di antaranya: (1) "Konsep dan Aplikasi Kepemimpinan Profetik," dalam Jurnal Edukasi; ${ }^{14}$ (2) "Konstruk Teoritis dan Pengukuran Kepemimpinan Profetik," dalam Jurnal Psikologi; ${ }^{15}$ (3) "Prophetic Leadership Model: Conceptualizing a Prophet's Leadership Behaviour, LeaderFollower Mutuality and Altruism to Decision Making Quality," dalam European Journal of Interdisciplinary Studies; ${ }^{16}$ (4) Buku Prophetic Leadership karya Rachmat Ramadhana Al-Banjari. 17 Secara keseluruhan studi-studi tersebut lebih banyak mengulas konseptualisasi terhadap karakteristik perilaku kepemimpinan Nabi, yang kemudian dikonstruk dalam kepemimpinan profetik. Permasalahan kaderisasi kepemimpinan tidak menjadi fokus utama kajian.

Dengan demikian studi ini memiliki nilai yang signifikan untuk dilakukan, sebab memiliki objek formal yang berbeda dengan studi-studi sebelumnya, baik yang mengkaji masalah kaderisasi kepemimpinan maupun karakteristik

14 Munardji, "Konsep dan Aplikasi Kepemimpinan Profetik," Jurnal Edukasi, Volume 04, Nomor 01, (2016): 68-86.

${ }^{15}$ Sus Budiharto \& Fathul Himam, "“'Konstruk Teoritis dan Pengukuran Kepemimpinan Profetik," Jurnal Psikologi UGM, Volume 33, Nomor 02, (2015): 133146.

16 Nik Maheran Nik Muhammad, "Prophetic Leadership Model: Conceptualizing a Prophet's Leadership Behaviour, Leader-Follower Mutuality and Altruism to Decision Making Quality," European Journal of Interdisciplinary Studies, Volume 03, Nomor 01, (2015): 93-107.

${ }^{17}$ Rachmat Ramadhana Al-Banjari, Prophetic Leadership, (Yogyakarta: Diva Press, 2008). 
kepemimpinan kenabian. Landasan teoritis yang digunakan sebagai panduan untuk meneliti proses kaderisasi kepemimpinan dalam organisasi dakwah Nabi adalah, pertama, konsep kaderisasi kepemimpinan yang merujuk pada konsep dari Smilansky, yaitu Developing Excecutive Talent, dan konsep pelatihan kepemimpinan dari Gary Yukl. Kedua, konsep kaderisasi kepemimpinan dakwah, yang mencakup karakteristik, kompetensi dan proses kaderisasinya. Kepemimpinan dakwah yang dimaksudkan adalah mencakup karakteristik kepemimpinan kenabian, sebagaimana yang dipraktikkan oleh Nabi Muhammad.

\section{Kaderisasi Kepemimpinan}

\section{Pengertian Kaderisasi Kepemimpinan}

Kaderisasi berasal dari kata kader, yang berarti orang yang diharapkan akan memegang peran yang penting dalam pemerintahan, partai, dan sebagainya. Kaderisasi atau pengaderan berarti proses, cara, perbuatan mendidik atau membentuk seseorang menjadi kader. ${ }^{18}$ Yukl menjelaskan bahwa kepemimpinan adalah proses untuk memengaruhi orang lain untuk memahami dan setuju dengan apa yang dilakukan dan bagaimana tugas itu dilakukan secara efektif, serta proses untuk memfasilitasi upaya individu dan kolektif untuk mencapai tujuan bersama. ${ }^{19}$ Robbins dan Judge mendefinisikan kepemimpinan sebagai kemampuan untuk memengaruhi sebuah kelompok untuk mencapai suatu

\footnotetext{
18 Tim Pusat Bahasa Indonesia, Kamus Besar Bahasa Indonesia Pusat Bahasa, Edisi Keempat, (Jakarta: Gramedia, 2008), 440.

${ }^{19}$ Gary Yukl, Kepemimpinan dalam Organisasi Edisi Kelima, diterjemahkan Budi Supriyanto, (Jakarta: Indeks, 2005), 8.
}

visi atau serangkaian tujuan tertentu. ${ }^{20}$ Kaderisasi kepemimpinan berarti proses, cara, perbuatan mendidik atau membentuk seseorang menjadi pemimpin. Dengan demikian kaderisasi kepemimpinan adalah proses mempersiapkan seseorang atau sekelompok orang, melalui metode pendidikan, pelatihan atau reproduksi kepemimpinan tertentu, untuk menjadi pemimpin pengganti di masa depan organisasi.

\section{Tahapan dan Proses Kaderisasi Kepemimpinan}

Secara prinsip, kaderisasi hampir sama dengan kegiatan pelatihan dan pengembangan SDM, hanya saja subjek yang dilatih dan dikembangkan adalah calon pemimpin atau eksekutif. Sehingga kaderisasi kepemimpinan merupakan pelatihan dan pengembangan SDM calon pemimpin. Smilansky menjelaskan supaya organisasi atau perusahaan mendapatkan talenta eksekutif/pemimpin masa depan, maka tahap pertama perlu dilakukan identifikasi/asesmen terhadap SDM yang dimiliki. Identifikasi tersebut tidak hanya terkait kinerja mereka dalam jabatannya saat itu, tetapi juga potensi SDM dalam menempati posisi masa datang. SDM yang dinilai memiliki kinerja tinggi dan potensi tinggi adalah calon yang menempati talenta berpotensi tinggi untuk kepemimpinan masa depan organisasi. ${ }^{21}$ Tahap selanjutnya adalah mengembangkan kapabilitas eksekutif. Talenta eksekutif yang telah diidentifikasi perlu untuk terus dikembangkan kapabilitasnya, baik secara pengetahuan, kompetensi, sikap, dan lain-

\footnotetext{
${ }^{20}$ Stephen P. Robbins \& Tinothy A. Judge, Perilaku Organisasi Buku 2 - Edisi 12, diterjemahkan Dian Angelica, Ria Cahyani, Abdul Rosyid, (Jakarta: Salemba Empat, 2008), 49.

${ }^{21}$ Smilansky, Developing Executive., 202.
} 
lain, sehingga ketika tiba waktunya menempati posisi eksekutif dengan tanggung jawab yang lebih besar telah siap untuk menghadapi berbagai tantangan. ${ }^{22}$ Pengembangan kapabilitas eksekutif merupakan pengembangan keterampilan kepemimpinan. Yukl menjelaskan bahwa terdapat tiga bentuk berbeda dari pengembangan keterampilan kepemimpinan, yaitu: (a) pelatihan formal, (b) aktivitas pengembangan yang ditanamkan dalam penugasan pekerjaan operasional atau dilakukan sejalan dengan penugasan tersebut, (c) aktivitas yang membantu sendiri. ${ }^{23}$ Efektivitas kegiatan pelatihan dan pengembangan keterampilan kepemimpinan juga bergantung pada kondisi organisatoris yang memudahkan atau menghalangi pembelajaran tersebut. Kondisi yang memudahkan seperti dukungan dari manajemen puncak, sistem penghargaan untuk mendorong pengembangan keterampilan, nilai-nilai budaya, dan sebagainya. ${ }^{24}$

\section{Identifikasi Talenta Eksekutif (Calon Pemimpin)}

Proses mengidentifikasi talenta eksekutif masa depan dimulai dari data manajemen kinerja SDM, yang tidak hanya terkait kinerja tetapi juga nilai potensi SDM. Smilansky menyarankan penilaian kinerja dan penilaian potensi dapat disusun dalam bentuk matriks sembilan kotak, sebagaimana dalam gambar $1 .{ }^{25}$

SDM-SDM yang berada pada posisi kotak sembilan yang berarti dinilai tinggi pada kinerja mereka saat ini, serta dinilai tinggi untuk potensi mereka, maka mereka itulah SDM yang berpotensi tinggi yang dapat membangun dasar kepemimpinan organisasi untuk masa datang. ${ }^{26}$ Sedangkan ketika menganalisis potensi, tidak fokus pada kompetensi-kompetensi tertentu, tapi pada penyebab kapabilitas yang membuat seseorang dapat mengembangkan kompetensinya pada posisi yang lebih senior nanti. Melalui kombinasi kesadaran diri serta kemampuan belajar, akan membuat seorang SDM dengan penyebabpenyebab kapabilitas yang dimiliki mampu membangun kompetensi-kompetensi yang diperlukan pada tingkat yang lebih tinggi. ${ }^{27}$

\section{Pelatihan dan Pengembangan Kapabilitas Kepemimpinan}

SDM-SDM potensial atau talenta eksekutif masa depan perlu untuk dikembangkan kapabilitasnya agar memiliki keterampilan kepemimpinan yang memadai untuk memegang posisi dan tanggung jawab tertinggi di organisasi, oleh karenanya perlu dilakukan pelatihan dan pengembangan keterampilan kepemimpinan sebagai bagian dari tahapan kaderisasi kepemimpinan itu sendiri. Smilansky menyarankan beberapa pendekatan yang bisa ditempuh guna melatih dan mengembangkan kapabilitas kepemimpinan SDM, sebagaimana dalam tabel 1.

\footnotetext{
22 Ibid., 220.

${ }^{23}$ Yukl., Kepemimpinan Dalam., 444.

24 Ibid., 444.

${ }^{25}$ Smilansky, Developing Executive., 177.
}

\footnotetext{
26 Ibid., 176.

27 Ibid., 178-179.
} 


\begin{tabular}{|c|c|c|c|}
\hline $\begin{array}{l}\text { Sangat } \\
\text { Efektif }\end{array}$ & $\begin{array}{l}\text { 4-SDM Profesional Tinggi } \\
\text { Secara konsisten memberikan } \\
\text { hasil istimewa dan berkinerja } \\
\text { tinggi. Sangat memahami } \\
\text { perkerjaan saat ini dengan baik. } \\
\text { Tetapi kemungkinan tidak dapat } \\
\text { menyesuaikan dengan situasi } \\
\text { baru secara efektif. }\end{array}$ & $\begin{array}{l}\text { 7-SDM Profesional Tinggi } \\
\text { Utilitas } \\
\text { Secara konsisten memberikan } \\
\text { hasil istimewa dan berkinerja } \\
\text { tinggi. Memahami pekerjaan } \\
\text { dengan baik dan memperbaiki } \\
\text { keah[annya. Dapat } \\
\text { menyesuaikan dengan situasi } \\
\text { baru sebagaimana diperhukan. }\end{array}$ & $\begin{array}{l}\text { 9-SDM Bïntang yang } \\
\text { Konsisten } \\
\text { Jelas berpotensi untuk } \\
\text { dipromosikan menempati peran } \\
\text { yang lebih besar. Menghadapi } \\
\text { tantangan organisasi dalam } \\
\text { meryediakan pehuang-peluang } \\
\text { untuk tumbuh kebih cepat. }\end{array}$ \\
\hline $\begin{array}{l}\mathbf{i} \\
\mathrm{n} \\
\mathrm{e} \\
\mathrm{r} \\
\mathrm{j} \\
\mathrm{a}\end{array}$ & $\begin{array}{l}\text { 2-SDM Profesional Tinggi } \\
\text { Masa Depan } \\
\text { Secara konsisten bekerja } \\
\text { memenuhi dan melampaui } \\
\text { harapan. Tetapi kemungkinan } \\
\text { tidak dapat menyesuaikan } \\
\text { dengan situasi baru secara } \\
\text { efektif. }\end{array}$ & $\begin{array}{l}\text { 5-SDM Profesional } \\
\text { Pengalaman } \\
\text { Secara konsisten memenuhi } \\
\text { harapan. Memahami perkerjaan } \\
\text { saat ini dan memperbaiki } \\
\text { keha[rannya. Dapat } \\
\text { menyesuaikan dengan situasi } \\
\text { baru sebagaimana diperhukan. }\end{array}$ & $\begin{array}{l}\text { 8-SDM Bintang Masa Depan } \\
\text { Secara konsisten memeruhi dan } \\
\text { melampaui harapan. Memahami } \\
\text { pekerjaannya dan memperbaiki } \\
\text { keah[an sewajarnya. Memiriki } \\
\text { keah[ian menghadapi tantangan } \\
\text { baru dan berbeda secara } \\
\text { konsisten. }\end{array}$ \\
\hline & $\begin{array}{l}\text { 1-SDM Knerja Rendah } \\
\text { Tidak memberikan hasil } \\
\text { sebagaimana yang diharapkan. } \\
\text { Kurang mampu dalam } \\
\text { pengembangan. }\end{array}$ & $\begin{array}{l}\text { 3-SDM Tidak Konsisten } \\
\text { Hasil pekerjaan tidak konsisten. } \\
\text { Memahami tugas } \begin{array}{r}\text { dan } \\
\text { kemungkinan }\end{array} \\
\begin{array}{l}\text { dapat } \\
\text { menyesuaikan dengan situasi } \\
\text { baru apabila diperkukan. }\end{array}\end{array}$ & $\begin{array}{l}\text { 6-SDM Intan Belum Terasah } \\
\text { Mencapai hasil sebagaimana } \\
\text { diharapkan. } \\
\text { pekerjaannya dan kemungkinan } \\
\text { pembelajar yang aktif. Memiliki } \\
\text { keah Ian menghadapi tantangan } \\
\text { baru dan berbeda secara } \\
\text { konsisten. }\end{array}$ \\
\hline $\begin{array}{l}\text { Kurang } \\
\text { Efektif }\end{array}$ & $\begin{array}{l}\text { Kurang mampu dalam } \\
\text { pengembangan }\end{array}$ & \multirow[t]{2}{*}{ Potensi } & \multirow[t]{2}{*}{$\begin{array}{l}\text { Lebih mampu dalam } \\
\text { pengembangan }\end{array}$} \\
\hline $\begin{array}{l}\text { Proses } \\
\text { - Ting } \\
\text { - Ting }\end{array}$ & $\begin{array}{l}\text { iptaan/kaderisasi kepem } \\
\text { ertama } \rightarrow \text { Kotak 9, 8, } 7 \\
\text { erikutnya } \rightarrow \text { Kotak 6, } 5\end{array}$ & & \\
\hline
\end{tabular}

Gambar 1 - Matriks Identifikasi Pemimpin Masa Depan menurut Smilansky

Tabel 1 - Pendekatan Pengembangan Kapabilitas Kepemimpinan menurut Smilansky ${ }^{28}$

\begin{tabular}{l|l|l|l}
\hline No & Pendekatan & \multicolumn{1}{c}{ Penjelasan } \\
\hline 1 & $\begin{array}{l}\text { Memberikan } \\
\text { Pemahaman } \\
\text { (Insight) }\end{array}$ & $\begin{array}{l}\text { Proses individu SDM potensial melalui serangkaian pertemuan dan } \\
\text { pembimbingan untuk meresapi apa yang perlu dilakukan untuk membangun } \\
\text { kekuatan yang dimiliki agar istimewa dalam bidang tersebut. Sebab } \\
\text { peningkatan kompetensi manajerial dan kepemimpinan salah satunya } \\
\text { bergantung pada pemahaman mengenai kekuatan dan kelemahan serta } \\
\text { kemampuan belajarnya sehingga dengan pemahaman yang baik } \\
\text { memungkinkan SDM potensial untuk berkembang. }\end{array}$ \\
3 & $\begin{array}{l}\text { Program } \\
\text { Pelatihan } \\
\text { nisasi } \\
\text { Pembinaan atau } \\
\text { Bimbingan } \\
\text { (Coaching) dan } \\
\text { Mentor Internal } \\
\text { Forum-Forum } \\
\text { Strategis }\end{array}$ & $\begin{array}{l}\text { Program pelatihan formal yang disediakan oleh perusahaan/organisasi, } \\
\text { fokusnya dapat berupa: (a) sesuai dengan kebutuhan kompetensi peralihan } \\
\text { jabatan kunci dalam hierarki manajemennya, (b) format modul terbagi dalam } \\
\text { beberapa bidang manajemen dan kepemimpinan. } \\
\text { Bentuk masukan dari eksekutif senior (yang telah berpengalaman dan berhasil) } \\
\text { kepada SDM potensial. Pembinaan juga memanfaatkan tenaga/ahli dari } \\
\text { eksternal perusahaan sebagi tenaga pembina pada bidang tertentu. }\end{array}$ \\
& $\begin{array}{l}\text { Mengikutsertakan SDM potensial dalam forum-forum strategis organisasi, } \\
\text { untuk membantu mereka mengembangkan perspektif yang luas terhadap } \\
\text { keseluruhan masalah organisasi. Dapat juga berbentuk pembelajaran dengan } \\
\text { kegiatan langsung (ide-ide pemecahan masalah). }\end{array}$ \\
\hline
\end{tabular}

28 Ibid., 221-232. 


\begin{tabular}{l|l|l}
\hline No & Pendekatan & \multicolumn{1}{c}{ Penjelasan } \\
\hline 5 & $\begin{array}{l}\text { Penugasan } \\
\text { (Assignment) }\end{array}$ & $\begin{array}{l}\text { SDM potensial diberikan penugasan ringkas dalam jangka waktu tertentu, } \\
\text { sehingga bisa memahami isu-isu riel yang ada di organisasi, memperluas } \\
\text { wawasan, ide-ide pemecahan masalah, dan peningkatan kemampuan. }\end{array}$ \\
6 & $\begin{array}{l}\text { Pengembangan } \\
\text { Pribadi }\end{array}$ & $\begin{array}{l}\text { Aktivitas yang dapat dilakukan secara mandiri oleh SDM potensial guna } \\
\text { meningkatkan kapabilitasnya, seperti membaca buku-buku yang relevan, } \\
\text { belajar dari sumber-sumber online, dan sebagainya. }\end{array}$ \\
\hline
\end{tabular}

Yukl menjelaskan terdapat tiga teknik khusus untuk pelatihan formal kepemimpinan, yaitu (a) pembuatan model peran perilaku, SDM yang dilatih mengamati seseorang yang mendemonstrasikan bagaimana menyelesaikan masalah tertentu, kemudian mereka mempraktikkan perilaku tersebut dalam permainan peran dan mendapatkan umpan balik; (b) diskusi kasus, kasus merupakan gambaran dari peristiwa dalam organisasi, mendiskusikan kasus meningkatkan pemahaman mengenai situasi riel, permasalahan dan pemecahannya; (c) simulasi skala besar, hampir sama dengan diskusi kasus, SDM yang dilatih akan dihadapkan masalah rumit dan membuat keputusan, bedanya mereka harus menghadapi/menanggung dari konsekuensi keputusannya. 29 Sedangkan aktivitas pengembangan kepemimpinan menurut Yukl, penekanannya adalah pada belajar dari pengalaman riel selama SDM menempati posisi tertentu di organisasi. Aktivitas tersebut di antaranya: lokakarya umpan balik multisumber, penugasan pengembangan, program rotasi pekerjaan, belajar bertindak, pemberian nasihat (mentoring), program tantangan luar (outdoor), dan lain-lain. ${ }^{30}$ Pendekatan lain yang disarankan Yukl adalah aktivitas membantu diri sendiri. Aktivitas tersebut bergantung pada individu calon pemimpin

${ }^{29}$ Yukl., Kepemimpinan Dalam., 448-451.

30 Ibid., 453-456. untuk memperkuat keterampilan kepemimpinannya, seperti mengembangkan visi pribadi dari sasaran karier, belajar dari kesalahan, belajar memandang peristiwa dari berbagai perspektif dan lan-lain. ${ }^{31}$

\section{Kaderisasi Kepemimpinan Dakwah}

\section{Pengertian dan Karakteristik}

\section{Kepemimpinan Dakwah}

Hakikat kepemimpinan dakwah adalah kemampuan untuk memengaruhi dan menggerakkan orang lain untuk mencapai tujuan tertentu, ${ }^{32}$ yaitu tujuan dakwah secara umum maupun tujuan organisasi dakwah secara khusus. Tujuan dari dakwah adalah untuk memecahkan permasalahan umat, membangun masyarakat, di samping juga berorientasi menglslamkan orangorang yang dipandang belum mengetahui ajaran Islam. ${ }^{33}$ Karakteristik kepemimpinan dakwah, di antaranya, pertama, secara normatif karakteristik kepemimpinan dakwah setidaknya harus berprinsip pada etika tauhid, tanggung jawab dalam organisasi, keadilan, dan melayani. ${ }^{34}$ Kedua, kepemimpinan dalam organisasi dakwah tidak terlepas dari peranannya sebagai subjek dakwah atau dai, artinya pemimpin

\footnotetext{
31 Ibid., 469-470.

32 Munir \& Illaihi, Manajemen Dakwah., 215

${ }^{33}$ Iskandar Al-Warisy, Dakwah Ilahiyah, (Surabaya: Yayasan Al-Kahfi, 2009), 3.

${ }^{34}$ Rivai \& Mulyadi, Kepemimpinan Dalam., 10-11.
} 
dakwah juga memiliki tanggung jawab untuk mengarahkan, memengaruhi dan mengomunikasikan nilai-nilai Islam kepada bawahannya, sehingga tugas kepemimpinan dan dai dapat dijalankan sekaligus. ${ }^{35}$ Ketiga, kepemimpinan dakwah harus dilandasi kepemimpinan demokratis yang menerapkan prinsip-prinsip yang berhubungan dengan spesialisasi tugas, pendelegasian wewenang, rentang pengawasan yang konsisten, dan lain-lain. ${ }^{36}$ Keempat, kepemimpinan dakwah haruslah menghargai aktivitas kemanusiaan sebagai penentu keberhasilan untuk mencapai tujuan dakwah, sangat menghargai kreatifitas individu, mendorong inovasi, menghargai adaptasi, dan meningkatkan loyalitas dalam proses pengembangan dakwah. ${ }^{37}$ Kelima, kepemimpinan dakwah harus mencerminkan karakter dasar kepemimpinan profetik, yaitu kemampuan seseorang untuk memengaruhi orang lain mencapai tujuan sebagaimana para nabi dan rosul (prophet) melakukannya. ${ }^{38}$ Dimensi kepemimpinan profetik terdiri dari empat aspek, yaitu sidiq, amanah, tabligh, dan fathonah. ${ }^{39}$

\section{Kompetensi Kepemimpinan Dakwah}

Kompetensi mencakup sejumlah pengetahuan, keterampilan, sikap atau perilaku lain yang bersifat esensial guna menyelesaikan pekerjaan, memberikan kontribusi terhadap kesuksesan organisasi dan memberi pembedaan kinerja

\footnotetext{
${ }^{35}$ Munir \& Illaihi, Manajemen Dakwah., 229-230.

36 Ibid., 215.

37 lbid., 215.

38 Adz-Dzakiey, "Menumbuhkan dan Mengembangkan Potensi Kepemimpinan melalui Prophetic Intelligence Management," dalam Hand Out Kuliah Studi Kepemimpinan Islam, (Yogyakarta: Universitas Cokroaminoto, 2005).

${ }^{39}$ Budiharto \& Himam, "Konstruk Teoritis." Jurnal Psikologi., 143.
}

superior. ${ }^{40}$ Kompetensi kepemimpinan dakwah mencakup sejumlah pengetahuan, keterampilan, sikap/perilaku, dan karakter yang diperlukan dalam rangka melaksanakan kepemimpinan dakwah yang dapat dirinci sebagai berikut: (a) kemampuan konseptual/penalaran, yang didasari atas pengetahuan dan wawasan riel tentang dakwah, keorganisasian dan manajemen dakwah; (b) kemampuan antarpribadi, seperti memahami perasaan/empati dan memotivasi subjek dan mitra dakwah, menerjemahkan visi misi dakwah, membangun kerjasama tim dalam organisasi dakwah, mengomunikasikan gagasan dakwah dengan jelas dan persuasif dan sebagainya; (c) pengetahuan dan kemampuan yang bersifat teknis, seperti pengetahuan tentang produk yang didakwahkan, karakteristik dan kultur organisasi dakwah, kemampuan komunikasi dakwah, dan sebagainya; (d) memiliki sikap/perilaku dan karakteristik yang sejalan dengan nilai-nilai dakwah, dan sejalan dengan karakteristik profetik, yaitu: iman dan takwa, shiddiq yang berarti jujur/benar, amanah yang berarti dapat dipercaya, tabligh yang berarti menyampaikan kebenaran, fathanah yang berarti cerdas/bijaksana, ikhlas dan istiqomah, ${ }^{41}$ serta keteladanan.

\section{Kaderisasi Kepemimpinan Dakwah}

Kaderisasi kepemimpinan dakwah berarti proses mempersiapkan seorang atau beberapa subjek dakwah untuk dididik, dilatih, dan dikembangkan menjadi pemimpin organisasi dakwah di masa yang akan datang. Tahapan kaderisasi

\footnotetext{
${ }^{40}$ Christine Manopo, Competency Based Talent and Performance Management System, (Jakarta: Salemba Empat, 2011), 40.

${ }^{41}$ Al-Banjari, Prophetic Leadership., 132-186.
} 
kepemimpinan dakwah terdiri dari dua hal, yaitu: (a) identifikasi subjek dakwah bertalenta eksekutif/pemimpin, dan (b) pelatihan dan pengembangan kapabilitas kepemimpinan dakwah. Identifikasi subjek dakwah bertalenta pemimpin dapat dilakukan dengan mengukur kinerja dakwah dan potensi subjek dakwah. Kinerja dakwah dapat dilihat melalui efektivitas dan konsistensi hasil kerja dalam pelaksanaan program dan proyek-proyek dakwah di organisasi. Potensi dapat dilihat tidak hanya dalam hubungannya dengan kemampuan pengembangan dan penyesuaian dengan situasi baru sebagaimana yang disampaikan Smilansky, tetapi juga sejauh mana potensi kemampuan konseptual, kemampuan antarpribadi serta karakter yang sejalan dengan nilai-nilai dakwah dan sifat-sifat rasul. Mereka yang memiliki kinerja konsisten dan potensi tinggi adalah SDM dakwah yang potensial menjadi talenta eksekutif masa depan.

Pelatihan dan pengembangan kapabilitas subjek dakwah talenta eksekutif diarahkan untuk memenuhi kompetensi kepemimpinan dakwah sesuai dengan lingkup dan skala organisasi yang akan dipimpin, mulai dari kemampuan konseptual, kemampuan antar pribadi, kemampuan teknis dan pembentukan karakter profetik sebagai pemimpin dakwah. Pendekatan dalam pelatihan dan pengembangan kapabilitas kepemimpinan dakwah dapat dilakukan dengan: (a) program/pelatihan formal organisasi dakwah, yang dapat dilakukan dengan pemberian pemahaman dan kesadaran terkait kepemimpinan dakwah, peningkatan pemahaman dakwah dan Islam, diskusi kasus permasalahan organisasi dakwah, pembuatan model peran perilaku pemecahan masalah dakwah, simulasi kasus dakwah yang riel, dan lain-lain; (b) pembimbingan dan mentoring internal, dapat dilakukan secara personal dari pemimpin dakwah kepada calon pemimpin, dapat diorientasikan untuk memberikan pemahaman terkait kapabilitas SDM, masukan-masukan, serta umpan balik; (c) melibatkan SDM calon pemimpin dalam forum-forum strategis organisasi dakwah, yang bertujuan untuk turut menggali permasalahan, mengumpulkan berbagai alternatif pemecahan dan pengambilan keputusan; (d) penugasan dalam proyek atau pelaksanaan program dakwah organisasi untuk jangka waktu tertentu, bisa dalam bentuk penugasan pengembangan, rotasi pekerjaan dakwah, dan lain-lain; (e) pengembangan pribadi oleh subjek dakwah calon pemimpin, melalui belajar mandiri, membaca buku, bertanya kepada ahli, mengembangkan visi pribadi yang sejalan dengan kebutuhan organisasi dakwah, dan lain-lain. Aspek penunjang yang juga penting dalam proses kaderisasi kepemimpinan dakwah adalah dukungan dari pemimpin dakwah, iklim belajar dalam organisasi dakwah dan kriteria pengembangan untuk penempatan dalam organisasi dakwah.

\section{Metodologi}

Metodologi studi ini adalah kualitatif ex post facto, karena tujuannya adalah untuk mengeksplorasi realitas tertentu, dan dilakukan setelah peristiwa terjadi. Studi ini juga menggunakan metodologi sejarah kepustakaan. Dalam metodologi penelitian dakwah, pendekatan sejarah dapat menjadi salah satu model untuk menggali manfaat 
dari sejarah dakwah Islam. ${ }^{42}$ Satuan konsep yang dianalisis adalah terkait: (1) konteks organisasi dan kepemimpinan Nabi sebagai situasi sosial yang melingkupi peristiwa kaderisasi kepemimpinan; (2) proses mendapatkan/mengidentifikasi SDM organisasi bertalenta eksekutif dalam lingkup organisasi dakwah Nabi; (3) proses mendidik/melatih dan mengembangkan kapabilitas SDM talenta eksekutif. Proses tersebut terkait subjek-subjek yang terlibat, aktivitas merekrut, mengidentifikasi, mendidik, membimbing, mengarahkan SDM, dan lain-lain, serta waktu dan tempat yang melingkupi. Data-data tersebut ditelusuri dalam literatur biografi dan kepemimpinan Nabi dan Sahabat, sehingga akan dapat mengungkap fakta-fakta sejarah atau kenyataan proses kaderisasi kepemimpinan organisasi Nabi yang terjadi (das sein). Dari situ bisa diambil nilai-nilai yang seharusnya (das sollen) sebagai pelajaran bagi proses kaderisasi kepemimpinan organisasi dakwah dewasa ini.

Teknik pengumpulan data dilakukan dengan pembacaan secara cermat dan kritis terhadap literatur sejarah yang digunakan sebagaimana yang disarankan Mestika Zed, ${ }^{43}$ dengan daftar literatur utama pada tabel 2. Teknik analisis yang digunakan adalah analisis kualitatif sebagaimana dalam model Miles dan Huberman, yaitu: reduksi data, penyajian data, dan penarikan kesimpulan. ${ }^{44}$ Reduksi data dilakukan dengan memilih,

${ }^{42}$ Asep Saeful Muhtadi dan Agus Ahmad Safei, Metode Penelitian Dakwah, (Bandung: Pustaka Setia, 2003), 122.

${ }^{43}$ Mestika Zed, Metode Penelitian Kepustakaan, (Jakarta: Yayasan Obor, 2004), 31.

44 Matthew B. Miles dan A. Michael Huberman, Analisis Data Kualitatif, diterjemahkan Tjejep Rohendi Rohidi, (Jakata: UI Press, 1992), 15-16. menyederhanakan, mentransformasikan dari keseluruhan data-data sejarah yang terkumpul ke dalam bentuk narasi ringkas fakta sejarah, serta membuang data-data yang tidak diperlukan. Penyajian data dalam bentuk narasi fakta sejarah, tabel dan skema. Penarikan kesimpulan dilakukan dengan mengidentifikasi polapola, alur sebab akibat, proposisi-proposisi, sejalan dengan analisis kesejarahan, yang meliputi teknik interpretasi dan historiografi. ${ }^{45}$

Tabel 2 - Daftar Literatur Utama yang Digunakan

\begin{tabular}{|c|c|c|}
\hline No & Judul Buku & Penulis \\
\hline 1 & Sirah Nabawiyah & $\begin{array}{l}\text { Ibnu Ishaq \& } \\
\text { Ibnu Hisyam }\end{array}$ \\
\hline 2 & $\begin{array}{l}\text { Sejarah Hidup dan } \\
\text { Perjuangan Rasulullah }\end{array}$ & Al-Mubarakfury \\
\hline 3 & Sejarah Hidup Muhammad & M.H. Haikal \\
\hline 4 & $\begin{array}{l}\text { Manhaj Haraki-Strategi } \\
\text { Pergerakan dan } \\
\text { Perjuangan Politik dalam } \\
\text { Sirah Nabi Saw. }\end{array}$ & Al-Ghadban \\
\hline 5 & $\begin{array}{l}\text { Sejarah dan Metode } \\
\text { Dakwah Nabi }\end{array}$ & $\begin{array}{l}\text { Ali } \quad \text { Mustofa } \\
\text { Yaqub }\end{array}$ \\
\hline 6 & $\begin{array}{l}\text { Nabi Muhammad sebagai } \\
\text { Seorang Pemimpin Militer }\end{array}$ & Afzalur Rahman \\
\hline 7 & Prophetic Leadership & R.R. Al-Banjari \\
\hline 8 & Tarikh Khulafa & As-Suyuthi \\
\hline 9 & $\begin{array}{l}\text { Al-Bidayah Wan Nihayah } \\
\text { Masa Khulafaur Rasyiddin }\end{array}$ & Ibnu Katsir \\
\hline 10 & $\begin{array}{l}\text { Karakteristik Perihidup } 60 \\
\text { Sahabat Rasulullah }\end{array}$ & Khalid M. Khalid \\
\hline 11 & Abu Bakar As Shiddiq & M.H. Haekal \\
\hline
\end{tabular}

45 Dudung Abdurrahman, Metode Penelitian Sejarah, (Jakarta: Logos Wacana Ilmu, 1992), 64, 67. 
Konteks Organisasi Dakwah dan Kepemimpinan Rasul

\section{Latar Belakang dan Tujuan Organisasi Dakwah Rasul}

Organisasi dakwah Rasul bermula ketika beliau mendapatkan wahyu yang memerintahkan untuk berdakwah. Nabi Muhammad awalnya mendakwahkan ajarannya secara sembunyi-sembunyi, sampai dengan tahun ketiga, terdapat sekitar enam puluh sahabat generasi pertama yang berasal dari semua lapisan masyarakat. ${ }^{46}$ Mereka itulah yang menjadi kader inti, yang kemudian diorganisir oleh Nabi, untuk mengembangkan dakwah Islam secara terbuka. ${ }^{47}$ Perjuangan organisasi dakwah Nabi terus berlanjut karena mendapatkan tantangan yang keras dari pemuka-pemuka masyarakatnya yang menolak, hingga umat Islam harus hijrah. Namun terus membangun kekuatan organisasinya sampai mendapatkan kemenangan. Dengan demikian latar belakang perlunya Nabi membangun suatu organisasi dakwah, di antaranya: (a) perintah dakwah untuk menyeru, mengajak masyarakatnya kepada Ketauhidan atau ajaran Islam;(b) Nabi menyadari bahwa mengajak/mendakwahkan Tauhid tidak mungkin sendirian, sebab yang dihadapi adalah masyarakat banyak, sehingga dibutuhkan kerjasama dengan orang lain; (c) Nabi memiliki kader-kader inti sebagai hasil dari dakwah, yang dibina secara langsung oleh Nabi, mereka inilah yang perlu untuk dikelola dan diorganisir sedemikian rupa dalam organisasi dakwah

46 Syaikh Munir Muhammad Al-Ghadban, Manhaj Haraki Strategi Pergerakan dan Perjuangan Politik Nabi Saw. Jilid 1, diterjemahkan Aunur Rafiq Shalih Tamhid, (Jakarta: Robbani Press, 1992), 23-26.

47 Muhammad Husein Haekal, Sejarah Hidup Muhammad, diterjemahkan Ali Audah, (Jakarta: Litera AntarNusa, 2013), 120-121.
Nabi. Dengan demikian tujuan dari organisasi dakwah Rasul adalah untuk membangun kekuatan umat Islam dalam rangka melaksanakan perintah dakwah, sebab dakwah akan lebih efektif dan efisien manakala dilakukan secara terorganisir. Adapun tujuan dari dakwah itu sendiri sebagaimana disampaikan Al-Warisy yaitu untuk memecahkan permasalahan umat dan mengislamkan orang-orang yang dipandang belum mengetahui ajaran Islam. ${ }^{48}$ Sehingga dapat disimpulkan, secara umum tujuan organisasi dakwah Nabi adalah untuk mencapai visi misi dakwah Ketauhidan.

\section{Lapangan Kerja Organisasi Dakwah Rasul}

Lapangan kerja organisasi dakwah adalah bidang garap dan langkah-langkah yang dikerjakan oleh organisasi dakwah dalam rangka untuk mencapai tujuan dakwah, termasuk di dalamnya adalah masyarakat yang didakwahi, materi yang didakwahkan, metode dan pendekatan dalam dakwah. ${ }^{49}$ Pertama, masyarakat yang menjadi sasaran dakwah. Nabi Muhammad diangkat di tengah-tengah masyarakat Mekkah sekaligus sebagai Nabi terakhir, sehingga masyarakat yang menjadi sasaran dakwahnya tidak hanya masyarakat Mekkah dan Arab tetapi juga masyarakat dunia. Masyarakat Mekkah dan Arab adalah masyarakat yang hidup atas dasar kesukuan, ikatan nilai-nilai kesukuan sangat kuat. Seseorang tidak bisa hidup tanpa perlindungan dari kabilah atau sukunya. Keadaan masyarakat Mekkah dan Arab saat itu digambarkan oleh Al-Mubarakfury sebagai berikut: (a) kondisi agama,

\footnotetext{
${ }^{48}$ Iskandar Al-Warisy, Dakwah Ilahiyah, (Surabaya: Yayasan Al-Kahfi, 2009), 3.

49 Ibid., 6-8.
} 
masyarakat Mekkah dan Arab saat itu menyembah berhala; (b) kondisi sosial, masyarakat Arab hidup berkelas dan bersuku-suku, sering terjadi pertikaian antar suku, wanita tidak ada harganya, perjudian dan minuman keras menjadi kebanggaan; (c) kondisi ekonomi, kemiskinan yang cukup mewarnai. ${ }^{50}$ Peradaban dan kebudayaan dunia saat itu didasarkan pada nilai-nilai materialistik semata, tanpa ada nilai-nilai moral yang mengarahkan peradaban dan kebudayaan tersebut ke jalan yang benar. ${ }^{51}$ Masyarakat saat itu disebut sebagai masyarakat jahiliyah (kebodohan), sebagai potret kebodohan dan kebobrokan para penyembah berhala bangsa Arab, Yahudi, Nasrani, Majusi, dan sebagainya. ${ }^{52}$

Kedua, materi yang didakwahkan. Inti materi yang didakwahkan adalah berisi pengetahuan Tauhid, oleh karenanya AlWarisyi menyebutnya sebagai dakwah ilahiah. 53 Tauhid merupakan unsur terpenting dari seluruh rangkaian dakwah Nabi, hal ini juga terkait dengan keadaan adanya berbagai penyimpangan Tauhid. ${ }^{54}$ Ketiga, tahapan kerja dakwah. AlMubarakfury membagi tahapan dakwah Rasulullah sebagai berikut: periode Mekah, yang terdiri atas: (a) dakwah sembunyisembunyi (tahun 0-3), (b) dakwah terangterangan di tengah penduduk Mekah

\footnotetext{
50 Syaikh Shafiyyurahman Al-Mubarakfury, Sirah Nabawiyah, diterjemahkan Kathur Suhardi, (Jakarta: Pustaka Al-Kautsar, 2012), 7-9.

51 Said Ramadhan Al-Buthy, Fikih Sirrah, diterjemahkan Fuad Syaifudin Nur, (Jakarta: Hikmah, 2009), 4-5.

52 Muhammad Ali, Muhammad The Prophet, diterjemahkan Suyud SA Syurayudha, (Jakarta: Darul Kutubil Islamiah, 2007), 9-10.

${ }^{53}$ Al-Warisyi, Dakwah Illahiah, 278.

${ }^{54}$ Rabi' bin Hadi Al-Madkhali, Manhaj Dakwah Para Nabi, diterjemahkan Abu fahmi, (Jakarta: Gema Insasni, 1992), 33.
}

(tahun 4-10), (c) dakwah di luar Mekah dan penyebarannya (tahun 11-13). Periode Madinah, yang terdiri atas: (a) masa banyak guncangan dan cobaan dari dalam dan luar (berakhir dengan perjanjian Hudaibiyah pada tahun $6 \mathrm{H}$ ), (b) masa perdamaian dengan para pemimpin paganisme (berakhir dengan Fathu Mekah pada tahun $8 \mathrm{H}$ ), (c) masa masuknya manusia ke dalam Islam dengan berbondong-bondong (berakhir dengan wafatnya Rasulullah pada tahun $11 \quad \mathrm{H}) . \quad{ }_{55}$ Keempat, metode/pendekatan dakwah. Selama Nabi menjalankan tugas dakwah, setidaknya terdapat enam pendekatan dakwah yang beliau lakukan, yaitu: (1) pendekatan personal dari mulut ke mulut, (2) pendekatan pendidikan, (3) pendekatan penawaran, (4) pendekatan misi, (5) pendekatan korespondensi/surat, (6) pendekatan diskusi. 56 Dalam menyampaikan dakwahnya, Nabi menggunakan cara-cara sebagai berikut: (1) disampaikan secara jelas dan terbuka, (2) tidak memaksa hanya sekedar menyampaikan, (3) tidak mencela tuhantuhan mereka, (4) dengan landasan hikmah, (5) tidak sebagai pengawas, (6) etika penyampaiannya, tidak bertentangan dengan ajaran tauhid. ${ }^{57}$

\section{Karakteristik Kepemimpinan Dakwah}

\section{Rasul}

Kepemimpinan dalam organisasi dakwah Rasul memiliki karakteristik khas yang juga memengaruhi sistem kaderisasi kepemimpinan di dalamnya. Kekhasan itu dapat dilihat dari tiga hal, yaitu, pertama, sumber kekuasaan atau pengaruh yang

\footnotetext{
${ }^{55}$ Al-Mubarakfury, Sirah Nabawiyah, 72-73.

${ }^{56}$ Ali Mustofa Yaqub, Sejarah dan Metode Dakwah Nabi, (Jakarta: Pustaka Firdaus, 2000), 124.

${ }^{57}$ Al-Warisyi, Dakwah Illahiah, 278.
} 
menjadi dasar legitimasi kepemimpinan Rasul. Dalam hal ini adalah diangkatnya beliau menjadi Rasul dan diberi wahyu oleh Allah. Hal ini menandakan bahwa Muhammad adalah orang terbaik di zamannya sehingga dipilih oleh Tuhan untuk menjadi Rasul. Namun legitimasi lain yang juga penting adalah kepercayaan masyarakat terhadap kapabilitas dan kredibilitas Muhammad sebagai seorang yang layak menjadi pemimpin. Jauh sebelum menjadi Nabi, Muhammad dikenal sebagai salah seorang pemikir dan memiliki akhlak yang terpuji, jujur, dan dapat dipercaya. Oleh karenanya tidak sedikit masyarakat kala itu mau menerima Islam karena melihat figur Muhammad. Kedua, orientasi kepemimpinan dakwah Rasul bukanlah kepemimpinan bersifat spiritual semata. Artinya sekalipun tujuannya adalah menyampaikan ajaran Tauhid, namun bukan berarti hal tersebut mengabaikan sendi-sendi lain kehidupan masyarakat. Sehingga kepemimpinan dakwah Nabi juga berorientasi untuk membangun masyarakat secara ukhrowi dan duniawi, menguatkan berbagai bidang, seperti kesejahteraan sosial, keadilan hukum, penyetaraan hak, dan sebagainya.

Ketiga, dalam pelaksanaan kepemimpinannya, terdapat beberapa prinsip yang ditekankan, yaitu musyawarah, keteladanan dan perhatian terhadap SDM. Kepemimpinan Rasulullah menerapkan prinsip asy-syura (musyawarah). Hal tersebut sebagaimana diperintahkan dalam Alquran, surah Alimran 159 dan Assyura 3638. Fakta sejarah menunjukkan bahwa musyawarah yang dilakukan oleh Nabi sebagai pemimpin dengan sahabatsahabatnya sangatlah banyak, seperti saat menghadapi Perang Badar, Perang Uhud,
Perjanjian Hudaibiyah, menghadapi kebohongan orang munafik, dan sebagainya. ${ }^{58}$ Rasulullah juga menyadari pentingnya suri tauladan yang baik dalam kepemimpinan. Sebagai pemimpin, Nabi tidak hanya memberikan instruksi, namun tidak jarang beliau turun tangan terlibat langsung di lapangan dalam berbagai proyek organisasi dakwah. Seperti dalam proyek pembangunan masjid di Madinah, beliau turut bekerja membangun masjid, ${ }^{59}$ demikian pula dalam hal budi pekerti, kesederhanaan hidup, kedermawanan, pengorbanan, dan sebagainya. Dalam kaitan dengan SDM-SDM-nya, Rasul menyadari bahwa SDM adalah aset penting dalam organisasi dakwah. Oleh karenanya Rasul senantiasa memberikan perhatian kepada SDM-nya, mendudukkan mereka sebagai insan manusia seutuhnya. Untuk itu SDM-SDM yang berhasil direkrut, khususnya di masa-masa awal, dididik secara langsung oleh Nabi. Terdapat dua tempat, dalam Nabi mendidik SDM-SDMnya di Mekkah, yaitu, di rumah sahabat Arqam bin Abi Arqam dan di rumah Nabi. ${ }^{60}$ Nabi juga memahami kelebihan dari tiap SDM sahabatnya, beliau tidak segan memberikan gelar atau kalimat pujian kepada sahabatnya. Seperti kepada Mushab bin Umair, Abdullah bin Masud, Salim Maula Abu Hudzaifah, dan sebagainya. ${ }^{61}$

Dari uraian di atas dapat disimpulkan bahwa konteks organisasi dakwah Rasul dan kepemimpinannya adalah: organisasi yang memasarkan nilai-niai

\footnotetext{
58 Ibid., 150.

59 Ibid., 210.

60 Yaqub, Sejarah dan Metode, 133-134.

${ }^{61}$ Khalid Muhammad Khalid, Karakteristik Perihidup Enam Puluh Sahabat Rasulullah, diterjemahkan Mahyuddin Syaf, dkk. (Bandung: Diponegoro, 1996).
} 
Tauhid, produknya sebagaimana yang ada dalam Alquran dan dicontohkan dalam perilaku Nabi; (2) organisasi dakwah Rasul dibangun mulai dari nol sampai dengan besar, didirikan pada abad enam Masehi, menyasar masyarakat Mekkah, Madinah, dan masyarakat Arab serta dunia; (3) organisasi dakwah Rasul memiliki tahapan kerja dakwah, yang secara umum bisa dibagi dalam dua periode dakwah, yaitu dakwah di Mekkah dan dakwah di Madinah; (4) kepemimpinan dakwah Rasul bercirikan legitimasi kepemimpinan yang diperoleh dari statusnya sebagai Nabi dan Rasul serta pengakuan masyarakat akan kualitas Muhammad; (5) kepemimpinan dakwah Rasul bukanlah kepemimpinan spiritual semata, tetapi kepemimpinan yang juga berorientasi sosial/pembangunan masyarakat; (6) dalam pelaksanaan kepemimpinan dakwah Rasul bercirikan kepemimpinan yang menggunakan musyawarah, menghidupkan suri tauladan, dan memberikan perhatian besar kepada SDM-nya.

\section{Proses Kaderisasi}

\section{Kepemimpinan Organisasi Dakwah Rasul}

\section{Identifikasi SDM Sahabat Bertalenta Eksekutif/Pemimpin}

Identifikasi yang dimaksud adalah proses Nabi dalam menilai dan memilih di antara para SDM subjek dakwah yaitu para sahabat, yang dipandang memiliki potensi untuk menjadi pengganti beliau sebagai pemimpin organisasi dakwah. Penilaian kinerja SDM dalam konteks organisasi dakwah Rasul diantaranya terkait: (a) kepercayaan dan loyalitas SDM terhadap organisasi dakwah, (b) konsistensi SDM dalam menghadapi problematika dakwah, (c) kuantitas dan kualitas peran SDM untuk pemecahan masalah dan kemajuan organisasi dakwah, serta (d) penyelesaian tugas-tugas yang diberikan pimpinan organisasi dakwah. Sedangkan penilaian potensi kepemimpinan terkait sejauhmana SDM memiliki pengetahuan, kemampuan, mental dan karakter dasar dalam kepemimpinan dakwah, yaitu: (a) kemampuan rasional/penalaran, (b) kemampuan antarpribadi, (c) mental dan karakter kepemimpinan dakwah, serta (d) pengetahuan yang bersifat teknis tentang visi misi organisasi dakwah, produk dakwah, kultur organisasi, dan sebagainya. Kombinasi hasil penilaian kinerja dan potensi yang tertinggi, sebagaimana dalam matriks Smiliansky, adalah mereka yang memiliki talenta eksekutif dan layak untuk dikader sebagai pemimpin.

Bukti bahwa Nabi melakukan identifikasi SDM sahabat yang dipandang memiliki talenta eksekutif, salah satunya adalah pada kasus Abu Bakar. Fakta sejarah mencatat bahwa Abu Bakar adalah khalifah pertama pengganti $\mathrm{Nabi}$, artinya dia adalah yang melanjutkan kepemimpinan organisasi dakwah Nabi. Abu Bakar adalah sahabat utama Nabi, bahkan sebelum beliau menjadi seorang Nabi, Abu Bakar dan Muhammad sudah menjalin persahabatan. Abu Bakar pula lelaki pertama yang menyatakan percaya terhadap wahyu dan kenabian Muhammad. Peranannya dalam pengembangan dakwah di Mekkah, serta posisinya sebagai wazir (pendamping/penasehat) Nabi selama di Madinah, 62 menunjukkan bagaimana

\footnotetext{
62 Musthafa Murad, Kisah Hidup Abu Bakar AsShiddiq, diterjemahkan Dedi Slamet Riyadi, (Jakarta: Zaman, 2007), 88-99; Muhammad Husein Haekal, Abu Bakar As-Shiddiq, diterjemahkan Ali Audah, Cetakan Ketiga, (Jakarta: Lentera AntarNusa, 2003), 22.
} 
kinerja dan potensi yang dimiliki Abu Bakar. Hal tersebut juga diakui sendiri oleh Nabi Muhammad, sebagaimana dalam pernyataannya dalam hadis berikut, "Sesungguhnya orang yang paling dekat persahabatannya dan penginfakkan hartanya untukku adalah Abu Bakar. Andaikata saya mengambil seseorang sebagai kekasih (khalil) selain Tuhanku, niscaya saya akan mengambil Abu Bakar sebagai kekasih dekatku (khalil). Namun kami terikat dengan persaudaraan seiman," (H.R. Bukhari dan Muslim). ${ }^{63}$

Setelah memimpin pelaksanaan ibadah haji, yang kemudian disebut sebagai Haji Wada' (Haji Perpisahan), Nabi mengalami demam tinggi. Ketika beliau tidak bisa memimpin salat, memerintahkan Abu Bakar sebagai pemimpin/imam salat. Bahkan ketika Umar memimpin salat dan terdengar oleh Nabi dari bilik Aisyah, beliau bertanya, "Mana Abu Bakar? Allah dan kaum muslim tidak menghendaki yang demikian (Umar sebagai pemimpin salat)." ${ }^{64}$ Data-data sejarah menunjukkan bahwa Nabi hanya rela jika kepemimpinan dalam salat dipegang oleh Abu Bakar, demikian pula pintu menuju masjid hanya untuk Abu Bakar. Sebagian ulama menegaskan bahwa fakta itu mengindikasikan isyarat atas kelayakan Abu Bakar sebagai pengganti Nabi (khalifah). Secara kredibilitas, karakter dan kontribusi terhadap perkembangan dakwah Islam, jasa-jasa Abu Bakar tidak diragukan oleh

${ }^{63}$ As-Suyuthi, Tarikh Khulafa, diterjemakan Samson Rahman, (Jakarta: Pustaka Al-Kautsar, 2011), 59.

64 Muhammad Husein Haekal, Sejarah Hidup Muhammad, diterjemahkan Ali Audah, Cetakan Keempatpuluh Satu, (Jakarta: Litera AntarNusa, 2013), 576-578; Karen Armstrong, Muhammad Biografi Sang Nabi, Cetakan Kedua, diterjemahkan Joko Sudaryanto, (Yogyakarta: Penerbit Jendela, 2004), 453-454; Maulana Muhammad Ali, The Early Caliphate (Khulafaur Rasyiddin), diterjemahkan Imam Musa, (Jakarta: Darul Kutubil Islamiyah, 2007), 10.
Nabi maupun sahabat-sahabat yang lain. Fakta-fakta tersebut menunjukkan bahwa Nabi melakukan identifikasi SDM sahabat yang dipandang memiliki talenta eksekutif sebagai pemimpin masa depan organisasi dakwah yang dibangunnya, dalam hal ini adalah terhadap sahabat Abu Bakar. Apabila dikaitkan dengan data kinerja dan potensi kepemimpinan yang dimiliki Abu Bakar, maka akan terlihat bagaimana kelayakan Abu Bakar sebagai SDM utama untuk menjadi pemimpin masa depan organisasi. Kinerja yang ditunjukkan oleh Abu Bakar dalam kepercayaan, loyalitas dan konsistensi serta peranannya dalam pengembangan organisasi dakwah Nabi, dapat dilihat pada tabel 3.

Sedangkan potensi kepemimpinan Abu Bakar diidentifikasi dalam beberapa fakta berikut: (a) sejak masa jahiliah (sebelum Islam datang), Abu Bakar adalah seorang pimpinan kabilah yaitu Bani Taim, dan menjadi salah seorang yang terpandang di kalangan Quraisy, dia memegang jabatan sebagai penyelesai masalah diyat (tebusan darah) dan segala macam ganti rugi; (b) Abu Bakar adalah seorang yang disukai masyarakatnya (kaum Quraisy), perangainya halus dan tenang, suka menolong, dan sering dijadikan rujukan pemecahan masalah; (c) Abu Bakar memiliki pikiran yang tajam, hal itu dibuktikan dengan penolakannya terhadap penyembahan berhala di masa jahiliyah juga terhadap khamr yang dipandangnya tidak membawa manfaat; (d) Abu Bakar termasuk orang yang memiliki pengetahun khususnya tentang genealogi kabilahkabilah Arab; (e) Abu Bakar juga salah seorang pedagang yang sukses di Mekkah. ${ }^{65}$

65 Haekal., Abu Bakar., 2-3; As-Suyuthi., Tarikh Khulafa., 35-36. 
Kombinasi potensi pikiran, pengalaman dan kemampuan dalam bidang kepemimpinan, pemecahan masalah dan komunikasi dengan orang lain membuat Abu Bakar sebagai seorang yang potensial sebagai pemimpin dakwah masa depan. Potensipotensi tersebut terbukti dalam peranan dan pelaksanaan tugas-tugas yang diamanahkan kepadanya dalam organisasi dakwah. Berdasarkan penilaian kinerja Abu Bakar selama ini, terkait keimanan, loyalitas, konsistensi, peranan dan keberhasilannya dalam menjalankan tugastugas organisasi serta potensi kemampuan berpikirnya, pengalaman kepemimpinan, berhubungan dengan orang lain serta pengetahuannya, membuat Abu Bakar layak untuk ditempatkan sebagai pilihan utama pengganti kepemimpinan organisasi dakwah selanjutnya. Studi dari Haryanto, menjelaskan bahwa Abu Bakar memiliki kompetensi utama dalam hal integritas, konsistensi, dan komitmen pada kebenaran, kepemimpinan dan kedermawanan. ${ }^{66}$ Atas dasar itulah (kinerja dan potensi Abu Bakar), Nabi menunjuk Abu Bakar sebagai imam salat ketika beliau sakit, dan memerintahkan umat Islam untuk mengikutinya sepeninggal beliau. Dengan demikian dalam kasus ini, proses identifikasi talenta eksekutif terbukti dilakukan oleh Nabi.

\footnotetext{
66 Haryanto, Rasulullah Way of Managing People, (Jakarta: Khalifa, 2008), 84.
}

Tabel 3 - Data Beberapa Kinerja Abu Bakar dalam Organisasi Dakwah Nabi

\begin{tabular}{|c|c|c|}
\hline $\begin{array}{l}\mathbf{N} \\
\mathbf{O}\end{array}$ & Peristiwa & $\begin{array}{c}\text { Kategori } \\
\text { Kinerja }\end{array}$ \\
\hline 1 & $\begin{array}{l}\text { Abu Bakar adalah lelaki } \\
\text { pertama yang percaya dan } \\
\text { tanpa ragu masuk Islam. }{ }^{67}\end{array}$ & $\begin{array}{l}\text { Kepercayaan } \\
\text { (Iman) }\end{array}$ \\
\hline 2 & $\begin{array}{l}\text { Abu Bakar adalah orang } \\
\text { yang membenarkan/percaya } \\
\text { terhadap peristiwa Isra } \\
\text { Mikraj Nabi Muhammad, } \\
\text { sehingga dia dijuluki As- } \\
\text { Shiddiq. }\end{array}$ & $\begin{array}{l}\text { Kepercayaan } \\
\text { (Iman) }\end{array}$ \\
\hline 3 & $\begin{array}{l}\text { Abu Bakar berhasil } \\
\text { mendakwahkan Islam di } \\
\text { kalangan penduduk Mekkah } \\
\text { yang lain, seperti Usman bin } \\
\text { Affan, Thalha bin Ubaidillah, } \\
\text { Abdurrahman bin Auf, } \\
\text { Zubair bin Awwam, Saad bin } \\
\text { Abu Waqash, dan lain-lain. }{ }^{69}\end{array}$ & $\begin{array}{l}\text { Peran } \\
\text { Dakwah }\end{array}$ \\
\hline 4 & $\begin{array}{l}\text { Abu Bakar dengan hartanya } \\
\text { membebaskan banyak } \\
\text { budak di Mekkah, seperti } \\
\text { Billal bin Rabbah, Zanirah, } \\
\text { dan lain-lain. }{ }^{70}\end{array}$ & $\begin{array}{l}\text { Peran } \\
\text { Dakwah }\end{array}$ \\
\hline 5 & $\begin{array}{lr}\text { Abu Bakar berhasil } \\
\text { melaksanakan tugasnya } \\
\text { dengan baik dalam } \\
\text { mendampingi Nabi } & \text { untuk } \\
\text { hijrah ke Madinah. } & \end{array}$ & $\begin{array}{l}\text { Peran dan } \\
\text { tugas }\end{array}$ \\
\hline 6 & $\begin{array}{l}\text { Abu Bakar bersama Umar } \\
\text { bin Khattab menjadi } \\
\text { penasehat/pembantu } \\
\text { (wazir) Nabi dalam } \\
\text { pemecahan masalah } \\
\text { organisasi dan umat selama } \\
\text { di Madinah. }{ }^{72}\end{array}$ & $\begin{array}{l}\text { Peran dan } \\
\text { tugas }\end{array}$ \\
\hline
\end{tabular}

${ }^{67}$ Haekal, Abu Bakar., 5; Murad., Abu Bakar., 26; AsSuyuthi, Tarikh Khulafa., 37-39.

${ }^{68}$ Haekal, Abu Bakar., 9-10; Murad., Abu Bakar., 35.

69 Ibnu Ishaq - Ibnu Hisyam, Sirah Nabawiyah, diterjemahkan Samson Rahman, (Jakarta: Akbarmedia, 2012), 157; Murad., Abu Bakar., 7.

70 Haekal, Abu Bakar., 8; Murad., Abu Bakar., 28-30;

${ }^{71}$ Haekal., Abu Bakar., 13-15; Murad., Abu Bakar., 92-99.

72 Haekal., Abu Bakar., 22; As-Suyuthi., Tarikh Khulafa., 55. 
Penelusuran lebih lanjut menunjukkan bahwa dalam proses kaderisasi kepemimpinannya, Nabi tidak hanya mengader seorang saja (dalam hal ini adalah Abu Bakar) yang nantinya dipersiapkan menjadi pemimpin organisasi masa depan. Namun dalam tiap lapisan generasi SDM sahabat, Nabi melakukan proses identifikasi terhadap SDM-nya yang dipandang memiliki talenta eksekutif organisasi dakwah. Lapisan generasi SDM sahabat yang dimaksud adalah keterlebihdahuluan dalam menerima Islam. Berdasarkan data sejarah lapisan generasi SDM sahabat dapat diklasifikasi sebagai berikut: pertama, lapisan generasi pertama sahabat adalah mereka yang mengikuti Islam dan berperan serta dalam organisasi dakwah Nabi sejak ketika di Mekkah hingga hijrah ke Madinah. Mereka adalah keluarga inti Nabi termasuk Ali bin Abi Thalib dan Zaid bin Harist yang diasuh oleh Nabi, sahabat Abu Bakar, orang-orang yang berhasil didakwahi Abu Bakar seperti Usman bin Affan, Abdurrahman bin Auf, Thalha bin Ubaidillah, Zubair bin Awwam, dan Saad bin Abu Waqash. Selain itu juga ada sahabat Abu Ubaidah, Abu Salamah, Arqam bin Abu Arqam, Usman bin Madzun, Said bin Zaid, Fatimah binti Khattab, Khabbab bin Arat, Abdullah bin Masud, Jakfar bin Abu Thalib, Abu Hudzaifah bin Rabiah, Salim maula Abu Hudzaifah, Mushab bin Umair, dan sebagainya. ${ }^{73}$ Termasuk juga Umar bin Khattab dan Hamzah bin Abdul Muthallib. Mereka adalah SDM yang sejak semula (di Mekkah) mengikuti dakwah Nabi, mendapatkan tekanan dan intimidasi dari kafir Quraisy, sampai harus hijrah ke Madinah. Diperkirakan jumlahnya sekitar 150-200

73 Ishaq \& Hisyam., Sirah Nabawiyah., 157-160; Armstrong., Muhammad Biografi., 157-160. orang. Dalam sejarah mereka dikenal sebagai kaum Muhajirin.

Kedua, lapisan generasi berikutnya adalah SDM sahabat dari Madinah. Mereka adalah peserta Baiat Aqabah Pertama dan Kedua yaitu sejumlah 75 orang, ${ }^{74}$ serta orangorang Madinah lain yang menerima Islam dan menolong kaum muslim Mekkah yang hijrah ke Madinah. Dalam sejarah mereka dikenal sebagai kaum Ansar. Nama-nama mereka diantaranya Asad bin Zurrah, Saad bin Muadz, Usaid bin Hudhair, Barra' bin Ma'rur, Ubadah bin Shamit, Muadz bin Jabbal, Kaab bin Malik, Saad bin Ubadah, Abdullah bin Rawahah, Abu Ayub Al-Ansari, dan sebagainya. ${ }^{75}$ Kaum Ansar adalah kelompok yang berjasa besar terhadap pengembangan organisasi dakwah Nabi. Melalui pertolongan kaum Ansar, organisasi dakwah Nabi memiliki tempat/pusat kegiatan dakwah baru, ketika di Mekkah sudah tidak memungkinkan lagi sebagai pusat dakwah. Kaum Ansar juga banyak terlibat dalam berbagai proyek peperangan seperti Perang Badar, Perang Uhud, Perang Ahzab, dan lain-lain.

Ketiga, adalah generasi SDM sahabat yang menerima Islam setelah peristiwa hijrah dan penaklukan Mekkah. Mereka adalah orang-orang yang pernah menolak dakwah Islam bahkan memusuhi dakwah Nabi, tetapi kemudian menyadari kebenaran yang dibawa oleh $\mathrm{Nabi}$ dan bersedia mengikuti Islam dan bergabung dengan organisasi dakwah Nabi. Mereka di antaranya adalah Khalid bin walid, Amr bin Ash, Suhail bin Amr, Yazid bin Abu Sofyan, Muawiyah bin Abu Sofyan, Abdurrahman bin Abu Bakar, dan sebagainya. Keempat,

\footnotetext{
74 Ibid., 276-281.

75 Ibid., 276-281.
} 
adalah generasi SDM sahabat yang sewaktu Nabi masih hidup, masih berusia remaja atau anak-anak. Mereka adalah putra dan putri para sahabat generasi pertama. Sehingga sejak kecil sudah dibesarkan di lingkungan keluarga Islam, di antaranya adalah Usamah bin Zaid bin Harist, Abdullah bin Zubair bin Awwam, Abdullah bin Abbas bin Abdul Muthallib, Abdullah bin Umar bin Khattab, Hasan bin Ali bin Abi Thalib, dan sebagainya.

Empat lapisan generasi SDM sahabat di atas sekaligus menggambarkan tingkat kinerja mereka dalam organisasi dakwah Nabi, khususnya terkait peran dan kontribusi yang sudah diberikan serta loyalitas dan konsistensi terhadap organisasi dakwah. Oleh karenanya lapisan generasi SDM sahabat pertama mendapatkan tempat prioritas dalam proses kaderisasi kepemimpinan. Tetapi tidak semua SDM sahabat generasi pertama diidentifikasi dan diproyeksikan menjadi pemimpin masa depan organisasi. Nabi memilih sahabat-sahabat tertentu yang dipandang memiliki kelayakan secara kinerja dan potensi dalam kepemimpinan. Sahabat seperti Abdullah bin Masud, Salim Maula Abu Hudziafah, Khabbab bin Arrats dinilai oleh Nabi memiliki talenta dalam bidang keilmuan, khususnya yang berhubungan dengan Alquran. Sahabat lain pada generasi pertama sebagian juga dinilai memiliki talenta yang berhubungan dengan kekuatan fisik seperti kemampuan bertarung dan berperang. Hamzah bin Abdul Muthallib memiliki talenta khusus tentang ini, sehingga dijuluki Singa Allah. ${ }^{76}$ Demikian pula Zubair bin Awwam yang dijuluki Pembela Rasul, ${ }^{77}$ juga Thalha bin

\footnotetext{
76 Ibid., 193.
}

77 lbid., 425.
Ubaidillah, Saad bin Abu Waqash, Zaid bin Khattab, dan lain-lain. Ali bin Abi Thalib dan Umar bin Khattab juga termasuk SDM sahabat yang memiliki kemampuan mumpuni dalam kekuatan fisik dan perang tanding.

Sehingga dalam lapisan generasi sahabat pertama, tidak semuanya diidentifikasi memiliki potensi kepemimpinan organisasi. Beberapa SDM sahabat juga dipandang tidak hanya memiliki satu potensi saja, tetapi juga beberapa potensi lainnya. Selain sahabat Abu Bakar yang diidentifikasi dapat menjadi talenta eksekutif masa depan sebagaimana di atas, terdapat sahabatsahabat lain yang dinilai oleh Nabi layak untuk ditempatkan sebagai SDM-SDM calon pemimpin organisasi dakwah masa depan. Penilaian itu dilihat dari kinerja SDM dalam organisasi dakwah dan potensi kemampuan, pengetahuan, dan moralitas yang dimiliki. Sahabat-sahabat itu di antaranya adalah Umar bin Khattab, Abu Ubaidah Al-Jarrah, Usman bin Affan dan Ali bin Abi Thalib. Fakta sejarah menunjukkan bahwa Umar bin Khattab adalah khalifah kedua penerus Abu Bakar, sedangkan Usman bin Affan adalah khalifah ketiga dan Ali bin Abi Thalib adalah khalifah keempat. Abu Ubaidah sekalipun tidak pernah menjadi khalifah tetapi dia adalah pemimpin Islam pertama di Syam (Syria) pada masa Kekhalifahan Umar bin Khattab. Mereka adalah sahabat-sahabat yang terbukti memiliki kapabilitas kepemimpinan organisasi dakwah yang baik. Selain namanama tersebut, terdapat sahabat generasi pertama lain yang berdasarkan fakta sejarah diindikasi memiliki kapabilitas kepemimpinan. Mereka adalah empat nama yang masuk dalam tim formatur sejumlah enam orang yang dibentuk di 
akhir masa Kekhalifahan Umar bin Khattab untuk melakukan musyawarah dan memutuskan salah satu di antara mereka agar menjadi khalifah pengganti Umar. Empat orang tersebut adalah Saad bin Abu Waqash, Zubair bin Awwam, Thalha bin Ubaidillah dan Abdurrahman bin Auf. Dua nama lainnya adalah Usman bin Affan dan Ali bin Abi Thalib. ${ }^{78}$ Termasuk juga sahabat Jakfar bin Abu Thalib, yang pada saat muslim Mekkah hijrah ke Habasyah, dia ditunjuk sebagai pimpinan dan juru bicaranya umat Islam di sana sampai dengan masa sebelum pembebasan Mekkah. ${ }^{79}$

Identifikasi talenta kepemimpinan terhadap sahabat-sahabat tersebut, khususnya Abu Bakar, Umar bin Khattab, Abu Ubaidah, Usman bin Affan, dan Ali bin Abi Thalib, dapat diketahui dari fakta penilaian dan pengakuan Nabi terhadap sahabat-sahabat tersebut, terkait kemampuan, pengetahuan, peranan yang diberikan terhadap organisasi, moralitas, gelar yang disematkan oleh Nabi, serta penugasanpenugasan yang diberikan oleh Nabi. Pada tabel 4 terdapat gambaran penilaian terhadap sahabat-sahabat tersebut (selain Abu Bakar) dalam bentuk pujian/pengakuan dan penugasan yang diberikan sebagai bentuk kepercayaan Nabi. Dengan demikian terdapat proses identifikasi terhadap SDM sahabat yang dipandang memiliki talenta eksekutif organisasi dakwah Nabi. Generasi sahabat pertama menjadi prioritas kaderisasi kepemimpinan, tempat Nabi mendapatkan
SDM-SDM sahabat yang bertalenta eksekutif.

Namun data sejarah menunjukkan bahwa Nabi juga memperhatikan SDM-SDM sahabat pada lapis generasi kedua, ketiga dan keempat untuk dikader sebagai pemimpin masa depan. Dalam proses kaderisasi kepemimpinan tersebut juga dilakukan tahapan identifikasi sebagaimana pada sahabat generasi pertama. Sebab faktanya tidak semua sahabat generasi kedua, ketiga dan keempat mendapatkan pujian/pengakuan serta tugas khusus yang utamanya berkaitan dengan kepemimpinan. Pada lapisan generasi kedua, terdapat beberapa nama sahabat Ansar yang dapat dijadikan contoh, seperti: (a) Abdullah bin Rawahah, dia adalah peserta Baiat Aqabah II, penulis dan pandai bersyair, dia dipilih Nabi untuk memimpin sekelompok pasukan menumpas beberapa kabilah yang hendak melawan Nabi. Abdullah bin Rawahah juga pernah ditunjuk sebagai pemimpin pengganti Nabi di Madinah, ketika Nabi melakukan satu ekspedisi ke luar. Abdullah bin Rawahah juga merupakan salah seorang yang ditugasi menjadi pemimpin pasukan muslim dalam Perang Mutah; ${ }^{80}$ (b) Saad bin Ubadah, dia merupakan salah satu dari 12 pemimpin Ansar yang terpilih dalam Baiat Aqabah II, Saad terkenal sebagai orang yang pemurah, membaktikan hartanya untuk kepentingan kaum Muhajirin. Saad juga sering ditugaskan sebagai pemimpin pasukan yang membawahi kaum Ansar. ${ }^{81}$

\footnotetext{
78 Muhammad Husein Haekal, Umar bin Khattab, Cetakan Kedua, diterjemahkan Ali Audah, (Jakarta: LiteraAntarnusa, 2009), 743-745

79 Khalid., Karakteristik Perihidup., 319-320.
}

\footnotetext{
${ }^{80}$ Khalid., Karakteristik Perihidup., 333-334, 336.

81 lbid., 571, 573-574.
} 
Tabel 4 -Pujian/Pengakuan dan Penugasan kepada SDM Sahabat Talenta Eksekutif

\begin{tabular}{|c|c|c|}
\hline No & $\begin{array}{c}\text { SDM } \\
\text { Sahabat }\end{array}$ & Pujian/Pengakuan dan Penugasan \\
\hline 1 & $\begin{array}{l}\text { Umar bin } \\
\text { Khattab }^{82}\end{array}$ & $\begin{array}{l}\text { a) Rasul memberikan gelar Al-Farouq (pembeda), karena Keislaman Umar } \\
\text { dinampakkan secara terang-terangan dan membedakan antara yang hak dan } \\
\text { yang bathil; } \\
\text { b) Rasul memuji kecerdasan Umar dengan berkata, "Sesungguhnya Allah } \\
\text { menjadikan kebenaran di lidah dan hati (pikiran) Umar," "Andaikata setelah aku } \\
\text { ada Nabi pastilah dia Umar" (H.R. Tirmidzi); } \\
\text { c) Umar berhasil memimpin sahabat lain hijrah ke Madinah (sejumlah } 20 \text { orang); } \\
\text { d) Umar bersama Abu Bakar ditempatkan sebagai wazir oleh Nabi selama di } \\
\text { Madinah; } \\
\text { e) Selama menjadi wazir, banyak masukan dari Umar yang direspon/dibenarkan } \\
\text { oleh wahyu Allah, di antaranya kasus tawanan perang badar, larangan menyalati } \\
\text { jenazah orang kafir, dan lain-lain. }\end{array}$ \\
\hline 2 & $\begin{array}{l}\text { Abu } \\
\text { Ubaidah }^{83}\end{array}$ & $\begin{array}{l}\text { a) Rasul memberinya gelar Amanatul Ummah (orang kepercayaan umat), yang } \\
\text { menunjukkan kualitas pribadi yang dimilikinya; } \\
\text { b) Abu Ubaidah ditugaskan sebagai pemimpin ekspedisi "Daun Khabath," yang } \\
\text { memimpin lebih dari } 300 \text { orang; } \\
\text { c) Abu Ubaidah ditugaskan untuk menjadi pemimpin utusan/duta Nabi menjadi } \\
\text { pengajar Islam di Najran; } \\
\text { d) Kepada utusan dari Najran, Nabi menyebut Abu Ubaidah sebagai orang yang } \\
\text { terpercaya, benar-benar terpercaya, diulang sampai dengan tiga kali. }\end{array}$ \\
\hline 3 & $\begin{array}{l}\text { Usman bin } \\
\text { Affan }^{84}\end{array}$ & $\begin{array}{l}\text { a) Rasul memberinya gelar Dzun Nurain (pemilik dua permata), karena Nabi } \\
\text { berkenan kepadanya untuk menikahkan dua putrinya (Ruqayyah binti } \\
\text { Muhammad, setelah meninggal, dinikahkan Nabi dengan Umi Kultsum binti } \\
\text { Muhammad). Ini mengindikasikan kepercayaan Nabi terhadap pribadi Usman; } \\
\text { b) Rasul memuji Usman sebagai salah seorang sahabat yang perilakunya mirip } \\
\text { dengan beliau, bahkan Rasul mengatakan malaikat pun malu/segan dengan } \\
\text { Usman; } \\
\text { c) Usman dan Ruqayyah diperintahkan Nabi mengikuti hijrah pertama ke } \\
\text { Habasyah; } \\
\text { d) Usman ditugaskan Nabi sebagai utusan kepada Quraisy dalam rangka umrah ke } \\
\text { Mekkah, yang kemudian menghasilkan Perjanjian Hudaibiyah; } \\
\text { e) Usman menjadi pemimpin pengganti Nabi di Madinah, selama Nabi } \\
\text { menjalankan ekspedisi Perang Dzat Ar-Riqa' dan Ghathafan. }\end{array}$ \\
\hline 4 & $\begin{array}{l}\text { Ali bin Abi } \\
\text { Thalib }^{85}\end{array}$ & $\begin{array}{l}\text { a) Ketika Nabi hijrah, Ali ditugaskan untuk menggantikan posisinya di tempat tidur } \\
\text { yang ketika itu rumah Nabi sudah dikepung dan hendak dibunuh; } \\
\text { b) Ketika Nabi mempersaudarakan antara sahabat Muhajirin dan Ansar di } \\
\text { Madinah, Nabi mengangkat Ali sebagai saudaranya, dan menyatakan sebagai } \\
\text { saudara di dunia dan akhirat; } \\
\text { c) Ali ditugaskan sebagai pemimpin pengganti Nabi di Madinah, selama Nabi } \\
\text { memimpin ekspedisi/Perang Tabuk, ketika itu Nabi menyatakan bahwa } \\
\text { posisinya adalah laksana Harun di samping Musa; } \\
\text { d) Nabi memuji kemampuan kepemimpinan Ali, dengan menyatakan bahwa, } \\
\text { barangsiapa yang menjadikan Aku sebagai pemimpin, maka Ali adalah } \\
\text { pemimpinnya. (H.R. Tirmidzi). }\end{array}$ \\
\hline
\end{tabular}

\footnotetext{
82 As-Suyuthi., Tarikh Khulafa., 129, 132-133, 138-140.

83 Khalid., Karakteristik Perihidup., 287, 290, 291.

${ }^{84}$ As-Suyuthi., Tarikh Khulafa., 173, 177, 176, 172.

85 Ibid., 194, 195, 196, 197.
} 
Sedangkan pada lapisan generasi ketiga sahabat, terdapat beberapa nama SDM sahabat yang cukup menonjol secara potensi dan kemampuannya, yang kemudian juga terbukti dalam pelaksanaan tugas-tugasnya, di antaranya adalah: (a) Amr bin Ash, dia adalah seorang pedagang yang sukses di kalangan Quraisy, seorang yang cerdik dan menjadi diplomat muda Quraisy. Ketika dia masuk Islam bersama Khalid bin Walid, Rasul memuji mereka sebagai putra-putra terbaik Quraisy. Sekalipun masih baru memeluk Islam, Rasul memberinya kepercayaan dalam beberapa proyek, termasuk menjadi perwakilan Rasul (pemimpin) di wilayah Oman; ${ }^{86}$ (b) Khalid bin Walid, ketika dia masuk Islam, Nabi berujar kepadanya, "Sungguh aku mengetahui anda (Khalid) mempunyai akal sehat (kecerdasan) dan aku mengharap akal itu yang akan menuntun pada jalan kebaikan..." Dalam Perang Mutah, setelah tiga pemimpin yang ditunjuk Nabi gugur, pimpinan diserahkan pada Khalid dan dia berhasil menyelamatkan sisa-sisa pasukan muslim. Tugas selanjutnya banyak diberikan kepada Khalid sebagai pimpinan dalam pasukan militer. ${ }^{87}$ Demikian pula dalam lapisan keempat generasi sahabat, yang merupakan kalangan anak muda dan remaja muslim. Rasul juga menyiapkan proses kaderisasi kepemimpinan bagi mereka. Salah satu indikasinya adalah pemilihan Usamah bin Zaid bin Harist yang kala itu masih berusia 18 tahun sebagai pimpinan pasukan yang terdiri atas 3000 orang, termasuk kaum Ansar dan Muhajirin dalam ekspedisi ke kota Balqa' (Yordania) ${ }^{88}$

\footnotetext{
86 Ibid., 675-679.

87 lbid., 341-344.

${ }^{88}$ Afzalur Rahman, Nabi Muhammad Sebagai Seorang Pemimpin Militer, Edisi Revisi,
}

Berdasarkan serangkaian data dan analisis di atas, dapat disimpulkan bahwa: (a) dalam proses kaderisasi kepemimpinan organisasi dakwahnya, terlebih dahulu Nabi melakukan identifikasi terhadap SDM sahabat yang dipandang memiliki talenta eksekutif; (b) dalam proses identifikasi SDM talenta eksekutif, Nabi memprioritaskan lapisan SDM sahabat generasi pertama, karena mereka adalah SDM yang secara kinerja dalam hal keimanan, loyalitas, konsistensi serta peranan dan penyelesaian tugas keorganisasian telah terbukti; (c) namun dalam tiap lapisan generasi SDM sahabat, diindikasi Nabi juga tetap melakukan identifikasi terhadap SDM-SDM yang dipandang memiliki talenta eksekutif; (d) selain memperhatikan aspek kinerja SDM sahabat, dalam proses identifikasi talenta eksekutif, Nabi juga memperhatikan potensi kepemimpinan yang dimiliki SDMnya. Potensi tersebut terkait kemampuan penalaran, moralitas, kemampuan komunikasi/hubungan antarpribadi dan sosial, pengalaman serta pengetahuan penunjang.

\section{Pelatihan dan Pengembangan} Kapabilitas Sahabat Calon Pemimpin

Tahap selanjutnya dalam proses kaderisasi kepemimpinan adalah pelatihan dan pengembangan SDM calon pemimpin. Dalam proses kaderisasi kepemimpinan organisasi dakwah Nabi, SDM sahabat yang telah diidentifikasi memiliki talenta eksekutif kemudian dipersiapkan sedemikian rupa, melalui berbagai sistem pelatihan dan pengembangan kapabilitas SDM sahabat calon pemimpin, supaya

diterjemahkan Anas Sidik, (Jakarta: Amzah, 2006), 111 
memenuhi kualifikasi kepemimpinan organisasi dakwah sesuai dengan yang diharapkan oleh Nabi. Oleh karenanya sebelum menguraikan lebih jauh pelaksanaan pelatihan dan pengembangan SDM sahabat calon pemimpin, akan diuraikan terlebih dahulu kualifikasi kepemimpinan seperti apa yang diharapkan oleh Nabi, yang nantinya melanjutkan kepemimpinan organisasi dakwah yang telah beliau bangun. Di atas telah disebut ciri kepemimpinan dakwah Rasul. Ciri kepemimpinan dakwah tersebut yang menjadi dasar kualifikasi kepemimpinan organisasi dakwah Rasul selanjutnya, yaitu sebagai berikut, pertama, kepemimpinan organisasi dakwah merupakan penerus misi dakwah Islam, oleh karenanya harus memiliki visi misi Keislaman yang kuat, keimanan, loyalitas dan konsistensi dalam organisasi dakwah. Kedua, proyek-proyek pembangunan masyarakat membutuhkan ilmu pengetahuan terkait serta pemecahan berbagai problematika umat, sehingga seorang yang menjadi pemimpin mestilah memiliki kemampuan penalaran yang tinggi dan ditunjang dengan pengetahuan terkait yang memadai. Pengetahuan terkait yang dimaksud adalah yang dibutuhkan dalam konteks pembangunan masyarakat di masanya, terutama dalam bidang-bidang prioritas. Ketiga, pelaksanaan musyawarah, selain menuntut kemampuan rasional pemimpin, juga menuntut kemampuan komunikasi/hubungan antarpribadi dan sosial yang baik dari seorang pemimpin, sehingga dia bisa mendengar pendapat orang lain sekalipun itu adalah rakyat biasa, dan meyakinkan pendapatnya dengan baik supaya bawahannya percaya dan mengikutinya. Keempat, pelaksanaan suri tauladan, menuntut pemimpin memiliki kualifikasi moral yang baik, sejalan dengan nilai-nilai dalam Alquran dan yang dicontohkan Rasul sendiri. Kelima, pelaksanaan perhatian kepada SDM, menuntut kemampuan pengelolaan SDM yang baik serta komunikasi/hubungan yang baik pula dengan SDM.

Sebagaimana kesimpulan sebelumnya, bahwa dalam proses kaderisasi kepemimpinan, Nabi memprioritaskan lapisan sahabat generasi pertama, maka demikian pula dalam proses pendidikan/pelatihan dan pengembangan SDM calon pemimpin, juga diprioritaskan pada lapisan sahabat generasi pertama. Tetapi Nabi juga memperhatikan SDM talenta eksekutif pada lapisan kedua, ketiga, dan keempat. Proses pendidikan kepemimpinan yang dilakukan oleh Rasul, secara periodesasi dakwah dan tempat, dapat diklasifikasi menjadi dua, yaitu: (a) pendidikan kepemimpinan di Mekkah, (b) pendidikan kepemimpinan di Madinah. Pertama, pendidikan kepemimpinan di Mekkah merupakan periode-periode awal dakwah sampai dengan sebelum hijrah. Penekanan pendidikan kepemimpinan pada masa ini adalah pembentukan pondasi keimanan dan visi Keislaman sebagai bagian dari kualifikasi dasar kepemimpinan dakwah serta membangun mentalitas dan moralitas yang sejalan dengan nilai-nilai Keislaman. Metode yang digunakan adalah melalui forum-forum pembelajaran yang diasuh secara langsung oleh Nabi. Terdapat dua tempat, yang digunakan, yaitu di rumah sahabat Arqam bin Abi Arqam dan di rumah Nabi. ${ }^{89}$ Selain itu proses pendidikan kepemimpinan di Mekkah juga melalui pembimbingan secara personal (mentoring and coaching). Dalam hal ini, Nabi bertindak sebagai mentor sekaligus pelatih

\footnotetext{
89 Yaqub, Sejarah dan Metode, 133-134.
} 
kepemimpinan, yang memberikan pemahaman, masukan dan pengarahan untuk membangun kapabilitas SDM sahabat agar memenuhi kualifikasi kepemimpinan yang diharapkan. Seperti pembimbingan dan pengarahannya kepada Jakfar bin Abi Thalib yang ditugaskan untuk hijrah ke Habasyah dan menjadi pemimpin umat Islam di sana, 90 juga pembimbingannya kepada Umar bin Khattab yang ketika itu baru masuk Islam pada tahun kelima Hijriah. Demikian pula kepada Abu Bakar, ketika melaksanakan proyek hijrah, Rasul memberikan pembimbingan kepadanya terkait ketenangan dan mentalitas dalam menghadapi kejaran orang-orang Quraisy.

Kedua, pendidikan kepemimpinan di Madinah yang merupakan kelanjutan pendidikan kepemimpinan di Mekkah. Pada masa ini, Nabi mulai memperhatikan pendidikan kepemimpinan pada lapisan SDM sahabat generasi kedua, ketiga dan keempat. Pusat pendidikan kepemimpinan di Madinah adalah di masjid, dengan menggelar forum-forum pembelajaran untuk peningkatan akidah dan pemahaman Alquran, serta visi Keislaman. Selain itu juga digelar forum-forum strategis untuk pemecahan masalah umat, yang tidak hanya melibatkan lapisan generasi pertama dan kedua, tetapi juga anak muda sebagai lapisan generasi keempat. Seperti dalam menghadapi tantangan perang oleh orangorang Quraisy yang hendak membalas kekalahan dalam Perang Badar, Nabi melibatkan beberapa generasi muda untuk pemecahan masalah tersebut. Proses pendidikan kepemimpinan di Madinah juga dilakukan melalui pendekatan personal

\footnotetext{
90 Khalid., Karakteristik Perihidup., 319-320.
}

melalui pembimbingan dan pengarahan. Seperti kepada Umar bin Khattab yang dikenal memiliki watak keras, Nabi beberapa kali mengajarkan kelembutan, sebagaimana dalam kasus Suhail bin Amr yang ketika itu menjadi tawanan Perang Badar, Umar minta izin Nabi agar mencabut gigi-giginya karena ucapannya selama ini kepada Islam. Tetapi Nabi tidak mengizinkan, karena perbuatan tersebut melanggar batas dan Nabi masih memiliki harapan bahwa kelak Suhail akan berubah dan menjadi pembela Islam, dan hal tersebut terbukti. ${ }^{91}$ Kepada Abu Bakar dan Umar, Nabi juga memberikan pembimbingan dan pengarahan khusus, terkait perannya sebagai penasehat pemimpin. Dalam kasus penunjukkan Usamah bin Zaid bin Harist sebagai pimpinan pasukan muslim, Nabi sebelumnya telah memberikan pengarahan dan pembimbingan khusus bagaimana menjadi pemimpin yang baik bagi pasukannya. Selain memberikan pendidikan/pelatihan untuk membentuk kompetensi dan moralitas kepemimpinan sebagaimana di atas, Rasul juga melakukan pengembangan talenta kepemimpinan SDM sahabat melalui beberapa proyek atau penugasan, sebagaimana dalam tabel 5 .

\footnotetext{
91 Khalid., Karakteristik Perihidup., 645-646.
} 
Tabel 5 - Beberapa Proyek/Penugasan untuk Pengembangan Kualifikasi Kepemimpinan SDM

\begin{tabular}{|c|c|c|c|c|}
\hline $\begin{array}{l}\mathbf{N} \\
\mathbf{O}\end{array}$ & Proyek/Penugasan & $\begin{array}{c}\text { SDM } \\
\text { Sahabat }\end{array}$ & $\begin{array}{c}\text { Kualifikasi/kompetensi yang } \\
\text { Dikembangkan }\end{array}$ & Kategori \\
\hline 1 & $\begin{array}{l}\text { Pimpinan dan juru bicara } \\
\text { umat Islam Mekkah yang } \\
\text { Hijrah ke Habasyah. }\end{array}$ & $\begin{array}{l}\text { Usman bin } \\
\text { Affan dan } \\
\text { Jakfar bin Abu } \\
\text { Thalib }\end{array}$ & $\begin{array}{l}\text { - Kemandirian pemecahan masalah } \\
\text { di wilayah baru. } \\
\text { - Mengomunikasikan ajaran Islam } \\
\text { ke Raja Najasyi yang beragama } \\
\text { Nasrani \& menghadapi duta } \\
\text { Quraisy. }\end{array}$ & $\begin{array}{ll}\text { - } & \text { Penalaran } \\
\text { - } & \text { Komunikasi } \\
& \text { antarpribadi } \\
\text { - } & \text { Pengetahuan } \\
\text { - } & \text { Kemampuan teknis }\end{array}$ \\
\hline 2 & $\begin{array}{l}\text { Memimpin satu } \\
\text { rombongan sahabat } \\
\text { untuk pawai/dakwah } \\
\text { terbuka di Mekkah. }\end{array}$ & $\begin{array}{l}\text { Umar bin } \\
\text { Khattab }\end{array}$ & $\begin{array}{l}\text { - Strategi dakwah secara terbuka di } \\
\text { masyarakat Mekkah. } \\
\text { - Keberanian menghadapi Quraisy }\end{array}$ & $\begin{array}{ll}\text { - } & \text { Penalaran } \\
\text { - } & \text { Kemampuan teknis } \\
\text { - } & \text { Loyalitas dan } \\
& \text { mentalitas }\end{array}$ \\
\hline 3 & $\begin{array}{l}\text { Mendampingi Nabi } \\
\text { hijrah ke Madinah. }\end{array}$ & Abu Bakar & $\begin{array}{l}\text { - Strategi supaya bisa keluar dari } \\
\text { Mekkah. } \\
\text { - Mentalitas dan ketahanan } \\
\text { menghadapi kejaran Quraisy. }\end{array}$ & $\begin{array}{ll}\text { - } & \text { Penalaran } \\
\text { - } & \text { Keimanan, loyalitas } \\
& \text { dan mentalitas } \\
\text { - } & \text { Kemampuan teknis }\end{array}$ \\
\hline 4 & $\begin{array}{l}\text { Menunjang kesuksesan } \\
\text { hijrah Nabi bersama Abu } \\
\text { Bakar. }\end{array}$ & $\begin{array}{l}\text { Ali bin Abi } \\
\text { Thalib }\end{array}$ & $\begin{array}{l}\text { - Strategi menggantikan Nabi di } \\
\text { posisi tempat tidurnya untuk } \\
\text { mengelabui Quraisy. }\end{array}$ & $\begin{array}{ll}\text { - } & \text { Strategi } \\
\text { - } & \text { Kemampuan teknis } \\
\text { - } & \text { Loyalitas dan } \\
& \text { moralitas }\end{array}$ \\
\hline 5 & $\begin{array}{l}\text { Memimpin satu } \\
\text { rombongan sahabat } \\
\text { (sekitar } 20 \text { orang) untuk } \\
\text { hijrah ke Madinah. }\end{array}$ & $\begin{array}{l}\text { Umar bin } \\
\text { Khattab }\end{array}$ & $\begin{array}{l}\text { - Strategi hijrah ke Madinah. } \\
\text { - Keberanian menghadapi Quraisy } \\
\text { yang menghalangi hijrah. }\end{array}$ & $\begin{array}{ll}\text { - } & \text { Penalaran } \\
\text { - } & \text { Loyalitas dan } \\
& \text { mentalitas } \\
\text { - } & \text { Pengetahuan dan } \\
& \text { kemampuan teknis }\end{array}$ \\
\hline 6 & $\begin{array}{l}\text { Mendamping Nabi } \\
\text { sebagai wazir/penasehat } \\
\text { dalam pemecahan } \\
\text { masalah organisasi } \\
\text { dakwah dan umat } \\
\text { selama di Madinah. }\end{array}$ & $\begin{array}{l}\text { Abu Bakar dan } \\
\text { Umar bin } \\
\text { Khattab }\end{array}$ & $\begin{array}{l}\text { - Pemecahan masalah tawanan } \\
\text { Perang Badar. } \\
\text { - Strategi menghadapi kaum } \\
\text { Munafik di Madinah dan Yahudi. } \\
\text { - Pemecahan masalah tanda } \\
\text { permulaan salat, masalah khamr, } \\
\text { dan masalah lainnya. }\end{array}$ & $\begin{array}{ll}\text { - } & \text { Penalaran } \\
\text { - } & \text { Pengetahuan } \\
& \text { terkait } \\
\text { - } & \text { Loyalitas }\end{array}$ \\
\hline 7 & $\begin{array}{l}\text { Menjadi pengganti Nabi } \\
\text { sebagai pemimpin } \\
\text { Madinah, selama Nabi } \\
\text { ekspedisi keluar } \\
\text { Madinah }\end{array}$ & $\begin{array}{l}\text { Usman bin } \\
\text { Affan; Ali bin } \\
\text { Abi Thalib, } \\
\text { dan sahabat } \\
\text { lain }\end{array}$ & $\begin{array}{l}\text { - Mengawasi pelaksanaan } \\
\text { kebijakan yang sudah ditetapkan } \\
\text { Nabi di Madinah. } \\
\text { - Pemecahan masalah umat } \\
\text { sementara Nabi tidak berada di } \\
\text { Madinah }\end{array}$ & $\begin{array}{ll}\text { - } & \text { Penalaran } \\
\text { - } & \text { Komunikasi } \\
& \text { antarpribadi } \\
\text { - } & \text { Loyalitas dan } \\
& \text { moralitas }\end{array}$ \\
\hline 8 & $\begin{array}{l}\text { Menjadi pimpinan } \\
\text { utusan dakwah di } \\
\text { beberapa wilayah }\end{array}$ & $\begin{array}{l}\text { Abu Ubaidah; } \\
\text { Ali bin Abi } \\
\text { Thalib; dan } \\
\text { sahabat lain }\end{array}$ & $\begin{array}{l}\text { - Strategi dakwah di wilayah } \\
\text { tertentu dan pemecahan masalah. } \\
\text { - Mengatur SDM yang mejadi } \\
\text { bawahan. }\end{array}$ & $\begin{array}{ll}\text { - } & \text { Penalaran } \\
\text { - } & \text { Komunikasi } \\
& \text { antarpribadi } \\
\text { - } & \text { Pengetahuan dan } \\
& \text { kemampuan teknis }\end{array}$ \\
\hline 9 & $\begin{array}{l}\text { Menjadi pimpinan } \\
\text { rombongan umat Islam } \\
\text { yang menunaikan ibadah } \\
\text { Haji tahun } 9 \mathrm{H}\end{array}$ & Abu Bakar & $\begin{array}{l}\text { - Mengatur rombongan haji dan } \\
\text { pemecahan masalah aktual terkait } \\
\text { pelaksanaan ibadah Haji sesuai } \\
\text { arahan Nabi }\end{array}$ & $\begin{array}{ll}\text { - } & \text { Penalaran } \\
\text { - } & \text { Komunikasi } \\
& \text { antarpribadi }\end{array}$ \\
\hline 10 & $\begin{array}{l}\text { Menjadi } \\
\text { pemimpin/imam salat } \\
\text { ketika Nabi sakit }\end{array}$ & Abu Bakar & $\begin{array}{l}\text { - Mengatur dan melaksanakan } \\
\text { ibadah salat sesuai dengan arahan } \\
\text { Nabi }\end{array}$ & $\begin{array}{l}\text { - Pengetahuan dan } \\
\text { kemampuan teknis }\end{array}$ \\
\hline
\end{tabular}




\section{Kesimpulan}

Secara garis besar proses kaderisasi kepemimpinan dalam organisasi dakwah Rasul dilaksanakan melalui dua tahapan, yaitu, pertama, identifikasi SDM sahabat yang dipandang memiliki talenta eksekutif. Kedua, pendidikan dan pengembangan kapabilitas SDM sahabat calon pemimpin. Terdapat empat lapisan SDM generasi sahabat, yaitu generasi pertama adalah kaum Muhajirin, generasi kedua adalah kaum Ansar, generasi ketiga adalah SDM yang memeluk Islam setelah penaklukan Mekkah, dan generasi keempat adalah para remaja, putra-putri sahabat generasi pertama dan kedua. Dalam proses identifikasi SDM talenta eksekutif, Nabi memprioritaskan lapisan SDM sahabat generasi pertama, karena mereka adalah SDM yang secara kinerja dalam hal keimanan, loyalitas, konsistensi serta peranan dan penyelesaian tugas keorganisasian telah terbukti. Namun terdapat indikasi dalam tiap lapisan generasi SDM sahabat, Nabi juga melakukan identifikasi terhadap SDM-SDM yang dipandang memiliki talenta eksekutif. Selain memperhatikan aspek kinerja SDM sahabat, dalam proses identifikasi talenta eksekutif, Nabi juga memperhatikan potensi kepemimpinan yang dimiliki SDMnya. Potensi tersebut terkait kemampuan penalaran, moralitas, kemampuan komunikasi/hubungan antarpribadi dan sosial, pengalaman serta pengetahuan penunjang.

Sedangkan proses pendidikan kepemimpinan dapat dibedakan menjadi pendidikan kepemimpinan di Mekkah dan pendidikan kepemimpinan di Madinah. Pendidikan kepemimpinan di Mekkah adalah tahap awal sehingga menekankan pada pembentukan keimanan dan visi Keislaman serta mentalitas dan moralitas. Pendekatan yang digunakan melalui forumforum pembelajaran bersama dan pembimbingan pengarahan personal dari Nabi kepada SDM sahabat bertalenta eksekutif. Pendidikan kepemimpinan di Madinah merupakan kelanjutan dari pendidikan kepemimpinan di Mekkah, yang lebih berorientasi pada kemampuan penalaran dan komunikasi pribadi, yang dilakukan melalui forum-forum strategis dengan melibatkan SDM talenta eksekutif serta pembimbingan dan pengarahan personal. Sementara proses pengembangan kapabilitas kepemimpinan dilakukan melalui berbagai penugasan khusus kepada SDM sahabat talenta eksekutif.

Hasil studi ini dapat menjadi gambaran dan inspirasi bagi organisasi dakwah pada hari ini guna menyiapkan sistem kaderisasi kepemimpinan di dalam organisasinya. Dalam tahap identifikasi talenta eksekutif, manajer organisasi dakwah perlu memperhatikan kinerja dan potensi kepemimpinan keseluruhan SDM yang dimiliki, artinya tidak hanya menyiapkan satu lapis generasi untuk kader pemimpin selanjutnya, tetapi juga beberapa generasi dibawahnya. Dalam tahap pendidikan dan pengembangan kapabilitas calon pemimpin, pada tahap awal manajer dakwah harus menekankan pada idealisme (keimanan) dan visi Keislaman dan organisasi dakwah yang dimiliki serta kompetensi kepemimpinan lainnya. 


\section{Bibliografi}

Abdurrahman, Dudung. Metode Penelitian Sejarah. Jakarta: Logos Wacana IImu, 1992.

Al-Banjari, Rachmat Ramadhana. Prophetic Leadership. Yogyakarta: Diva Press, 2008.

Al-Buthy, Said Ramadhan. Fikih Sirrah. Diterjemahkan Fuad Syaifudin Nur. Jakarta: Hikmah, 2009.

Al-Ghadban, Syaikh Munir Muhammad. Manhaj Haraki Strategi Pergerakan dan Perjuangan Politik Nabi Saw. Jilid 1. Diterjemahkan Aunur Rafiq Shalih Tamhid. Jakarta: Robbani Press, 1992.

Al-Madkhali, Rabi' bin Hadi. Manhaj Dakwah Para Nabi. Diterjemahkan Abu Fahmi. Jakarta: Gema Insani, 1992.

Al-Mubarakfury, Syaikh Shafiyyurahman. Sirah Nabawiyah. Diterjemahkan Kathur Suhardi. Jakarta: Pustaka Al-Kautsar, 2012.

Al-Warisy, Iskandar. Dakwah Ilahiyah. Surabaya: Yayasan Al-Kahfi, 2009. . Substansi Rasulullah dan Sunnahnya. Surabaya: Yayasan AI-Kahfi, 2001.

Ali, Maulana Muhammad. The Early Caliphate (Khulafaur Rasyiddin). Diterjemahkan Imam Musa. Jakarta: Darul Kutubil Islamiyah, 2007.

. Muhammad The Prophet. Diterjemahkan Suyud SA Syurayudha. Jakarta: Darul Kutubil Islamiah, 2007.

As-Suyuthi, Tarikh Khulafa. Diterjemakan Samson Rahman. Jakarta: Pustaka Al-Kautsar, 2011.

Budiharto, Sus \& Himam, Fathul. "Konstruk Teoritis dan Pengukuran Kepemimpinan Profetik." Jurnal Psikologi UGM, Volume 33, Nomor 02, (2015): 133-146.

Falah, Saiful., dkk. "Model Regenerasi dan Kaderisasi Kepemimpinan dalam Islam." Eduka Jurnal Pendidikan, Hukum dan Bisnis, volume II, nomor 2, (2016): 67-91.

Falah, Saiful. "Pendidikan Kepemimpinan M. Natsir dan Implementasinya di Lembaga Pendidikan," Edukasi Islami Jurnal Pendidikan Islam, Vol.04, Juli (2015).

Fathi, Muhammad. The Art of Leadership in Islam. Diterjemahkan Masturi Irham \& Malik Supar. Jakarta: Khalifa, 2007.

Haekal, Muhammad Husein. Abu Bakar As-Shiddiq. Cetakan Ketiga. Diterjemahkan Ali Audah. Jakarta: Lentera AntarNusa, 2003.

Sejarah Hidup Muhammad. Cetakan Keempatpuluh Satu. Diterjemahkan Ali Audah. Jakarta: Litera AntarNusa, 2013.

. Umar bin Khattab. Cetakan Kedua. Diterjemahkan Ali Audah. Jakarta: Litera AntarNusa, 2009.

Haryanto. Rasulullah Way of Managing People. Jakarta: Khalifa, 2008.

Ishaq, Ibnu - Hisyam, Ibnu. Sirah Nabawiyah. Diterjemahkan Samson Rahman. Jakarta: Akbarmedia, 2012.

Katsir, Ibnu. Al-Bidayah Wan Nihayah Masa Khilafaur Rasyiddin. Disusun Muhammad bin Shammil As-Sulami. Diterjemahkan Abu Ihsan Al-Atsari. Jakarta: Darul Haq, 2004.

Khalid, Khalid Muhammad. Karakteristik Perihidup Enam Puluh Sahabat Rasulullah. Diterjemahkan Mahyuddin Syaf, dkk. Bandung: Diponegoro, 1996.

Manopo, Christine. Competency Based Talent and Performance Management System. Jakarta: Salemba Empat, 2011. 
Masyhud, M. Suthon, dkk. Manajemen Pondok Pesantren. Jakarta: Diva Pustaka, 2008.

Miles, Matthew B. dan Huberman, A. Michael. Analisis Data Kualitatif. Diterjemahkan Tjejep Rohendi Rohidi. Jakata: UI Press, 1992.

Muhammad, Nik Maheran Nik. "Prophetic Leadership Model: Conceptualizing a Prophet's Leadership Behaviour, Leader-Follower Mutuality and Altruism to Decision Making Quality." European Journal of Interdisciplinary Studies, Volume 03, Nomor 01, (2015): 93-107.

Muhtadi, Asep Saeful dan Safei, Agus Ahmad. Metode Penelitian Dakwah. Bandung: Pustaka Setia, 2003.

Munardji. “Konsep dan Aplikasi Kepemimpinan Profetik." Jurnal Edukasi, Volume 04, Nomor 01, (2016): 68-86.

Munir, M. \& Ilaihi, Wahyu. Manajemen Dakwah. Jakarta: Kencana, 2006.

Murad, Musthafa. Kisah Hidup Abu Bakar As-Shiddiq. Diterjemahkan Dedi Slamet Riyadi. Jakarta: Zaman, 2007.

Qodir, Abdul dan Sarbiran, "Kaderisasi Kepemimpinan Agama Melalui Pondok Pesantren AlMunawir Krapyak Yogyakarta." Jurnal Penelitian dan Evaluasi, nomor 3, tahun II, (2000): 141-156.

Rahman, Afzalur. Nabi Muhammad Sebagai Seorang Pemimpin Militer, Edisi Revisi. Diterjemahkan Anas Sidik. Jakarta: Amzah, 2006.

Rivai, Vithzal \& Mulyadi, Deddy. Kepemimpinan dan Perilaku Organisasi. Jakarta: Rajawali Pers, 2012.

Robbins, Stephen P. \& Judge, Tinothy A. Perilaku Organisasi Buku 2 -Edisi 12. Diterjemahkan Dian Angelica, Ria Cahyani, Abdul Rosyid. Jakarta: Salemba Empat, 2008.

Smilansky, Jonathan. Developing Executive Talent. Diterjemahkan Octa Melia Jalal. Jakarta: PPM, 2008.

Tim Pusat Bahasa Indonesia. Kamus Besar Bahasa Indonesia Pusat Bahasa, Edisi Keempat. Jakarta: Gramedia, 2008.

Utama, Nita Erawati. "Kaderisasi Kepemimpinan Persis (Studi Deskripsi Persis di Kecamatan Bojongpicung Kabupaten Cianjur)." Thesis, UIN Sunan Gunung Djati, Bandung, 2010.

Yaqub, Ali Mustofa. Sejarah dan Metode Dakwah Nabi. Jakarta: Pustaka Firdaus, 2000.

Yuliati, Kadar. "Kaderisasi Kepemimpinan di Pondok Modern Darussalam Gontor Ponorogo Jawa Timur." Thesis, Pascasarjana UIN Sunan Kalijaga, 2015.

Yukl, Gary. Kepemimpinan dalam Organisasi Edisi Kelima. Diterjemahkan Budi Supriyanto. Jakarta: Indeks, 2005.

Zed, Mestika. Metode Penelitian Kepustakaan. Jakarta: Yayasan Obor, 2004 
Dedy Pradesa 